\title{
Access to infrastructure services: global trends and drivers
}

\author{
Jan Christoph Steckel ${ }^{a, b, c *}$, Narasimha D. Rao ${ }^{d}$, Michael Jakob ${ }^{a, c}$ \\ ${ }^{\text {a }}$ Mercator Research Institute on Global Commons and Climate Change, Torgauer Straße 12-15, 10829 Berlin, \\ Germany \\ ${ }^{\mathrm{b}}$ Technical University Berlin, Straße des 17. Juni 145, 10623 Berlin, Germany \\ 'Potsdam Institute for Climate Change Impact Research, Telegrafenberg, 14473 Potsdam, Germany \\ ${ }^{\mathrm{d}}$ International Institute of Systems Analysis, Ecosystems Services and Management, Schlossplatz 1, A-2361 \\ Laxenburg, Austria \\ *Corresponding author: steckel@mcc-berlin.net
}

The final publication is available at http://dx.doi.org/10.1016/j.jup.2017.03.001

Please cite as: Steckel, J. C., Rao, N. D., \& Jakob, M. (2017). Access to infrastructure services: Global trends and drivers. Utilities Policy. doi: 10.1016/i.jup.2017.03.001

\begin{abstract}
Infrastructure services are essential to human development. Yet, the drivers of service access at a global scale remain largely unexplored. This paper presents trends and global patterns in access to water, sanitation, electricity, and telephony services. Using a panel data set from 1990-2010, we empirically explore plausible determinants of access rates to key infrastructure services. Although per-capita GDP is correlated with access rates, access still varies significantly at comparable income levels. Much of this variation is explained by differences in population density. Access levels are higher for urban areas and highest for water, followed by sanitation, electricity, and telephony.
\end{abstract}

Keywords: Infrastructure access, Basic needs, SDGs, Fractional logit model, Global panel data 


\section{Highlights:}

Global trends and patterns indicate that:

- Infrastructure access varies widely among countries with similar incomes.

- Infrastructure development appears to follow a sequence, led by water access.

- Urban and denser populations seem to get higher priority in terms of infrastructure access. 


\section{Introduction}

Poverty is increasingly being understood and characterized as multi-dimensional rather than just in terms of income (Ravallion, 2011; Tsui, 2002). This view of poverty is fundamental to the United Nations Millennium Development Goals (UN, 2000) and prominent in discussions regarding the post2015 development goals (Fukuda-Parr, 2012) that aim to refine and extend the Millennium Development Goals for the period 2015-2030 (Griggs et al., 2013). Frequently discussed goals to advance human wellbeing include universal primary education, gender equality, child mortality, and AIDS/HIV and malaria eradication. It has further been argued that correcting under-provision of the material foundations necessary to fulfil basic human needs through expanded access to infrastructure for, inter alia, water, sanitation, electricity, telephony, education, and healthcare, should be regarded as one of the central aims of public policy (Jakob and Edenhofer, 2014). This view is consistent with a broader view in social policy of a universal entitlement to basic goods (Reinert, 2011).

Against this background, it comes as a surprise that the literature related to infrastructure (reviewed in Section 2) has largely neglected its role in the provision of services to fulfil basic needs. In particular, previous studies have mostly examined infrastructure as an explanatory variable to study other development indicators, such as economic growth and inequality, instead of seeking to understand the determinants and patterns of infrastructure access. By conceiving infrastructure services as ends in themselves instead of means to achieve other policy objectives, this paper aims to fill this gap. Using a panel data set from 1990-2010, we explore plausible determinants of access rates to four key infrastructure services: water, sanitation, electricity, and telephony. It is to our knowledge the first study that provides a comprehensive account of global patterns and trends in infrastructure provision for a global sample of 194 countries across more than two decades. In particular, it provides an empirical analysis of the determinants of access rates to these four key infrastructure services.

This paper proceeds as follows. Section 2 reviews the literature and discusses the motivation for our inquiry. Section 3 describes stylized facts that can be derived from existing data and develops key 
hypotheses, which we test using a fractional logit model introduced in Section 4. Section 5 presents and discusses results and Section 6 concludes.

\section{Literature}

Several contributions have analysed the importance of infrastructure for economic growth and development outcomes (see Romp and Haan (2007) for a survey). A seminal contribution by Aschauer (1989) identified the lack of public infrastructure, such as roads, sewers, and piped water, as one of the main reasons for declining productivity growth in the US. Even though this finding has been challenged by subsequent analyses (Gramlich, 1994), cross-country comparisons have frequently found positive effects of infrastructure on productivity (Irmen and Kuehnel, 2009). Agenor and Moreno-Dodson (2006) provide a discussion of the potential mechanisms that translate infrastructure into economic growth. For a sample of OECD countries, Demetriades and Mamuneas (2000) find positive effects of public infrastructure on productivity and employment, and Calderon and Serven (2014) note that on average, higher levels of infrastructure are related to higher rates of economic growth and lower economic inequality. This general finding is confirmed by a meta-review of similar studies by Straub (2011), who also found significant heterogeneity across countries and time. Other recent studies have refined the analysis by considering inter alia the direct consumption benefits of public infrastructure (Haughwout, 2002), taking into account the inter-regional productivity spill-overs of infrastructure (Cohen and Paul, 2004), as well as analysing the impacts of specific infrastructure policies, such as the effect of electrification programs on wages and employment in South Africa (Dinkelman, 2011) or on the performance of micro and small enterprises in Burkina Faso (Grimm et al., 2013). Peters and Sievert (2016) recently reviewed the development effects of rural electrification across different African countries. Others have investigated the effect of dams on agricultural productivity (Duflo and Pande, 2007) or the consequences of privatizing water services on child mortality in Argentina (Galiani, Gertler, and Schargrodsky, 2005). 
These studies have in common the treatment of infrastructure as an explanatory variable for a certain set of outcomes, such as economic growth. By contrast, the question of which factors determine the stock of a certain infrastructure or the extent of access to associated services has received surprisingly scant attention in the literature. Estache and Fay (2007) provide a broad descriptive overview of infrastructure investments, access rates, and policy debates related to infrastructure. Birdsall and Nellis (2003) examine the distributional effects of privatization of formerly public infrastructure on inter alia access to associated services. Castells and Sole-Olle (2005) observe that for the case of Spain, regional specific infrastructure needs and political factors seem to have more explanatory power for the geographical distribution of public infrastructure investment. Some authors also point out that public infrastructure investment is frequently employed as a vehicle for rent-seeking (Keefer and Knack, 2007) or a particularly inefficient redistribution device (Robinson and Torvik, 2005).

The paper closest to our study is Onyeji, Bazilian, and Nussbaumer (2012). Their empirical analysis focuses on the determinants of electricity access for a cross-section of sub-Saharan African countries, including poverty levels, gross domestic savings, energy-related gross fixed capital formation, rural population and population density. They highlight the importance of the size of the rural population and government effectiveness, finding that the latter plays a bigger role for electricity access in SubSaharan Africa compared to other world regions.

Our study goes beyond the existing literature in at least three ways. First, we analyse the determinants of access to (i) water, (ii) sanitation, (iii) electricity, and (iv) telephony instead of focusing on one particular infrastructure service. Second, we employ a broad sample of 194 countries, which allows us to derive inter-regional comparisons of infrastructure developments. Third, instead of relying on a cross section of data, we employ panel data for the time period 1990-2011, which enables us to analyse the evolution of access rates over time and also circumvent econometric issues related to unobserved heterogeneity (country-specific effects correlated with explanatory variables) that would introduce bias to cross-sectional estimates. 


\section{Stylized facts and hypotheses}

In this section, we first describe stylised facts and patterns for individual infrastructure services without necessarily implying any causality. We then develop hypotheses about causal determinants, which we examine more deeply in the next sections.

\subsection{Data and definitions}

We consider access to water, sanitation, electricity, and telephony. Access to water is defined as access to an improved water source (piped household water, public tap, tube well/borehole, protected dug wells, protected springs, rainwater collection); access to sanitation is improved sanitation facilities (flushed latrine, ventilated improved pit latrine, pit latrine with a slab or a composting toilet); access to electricity implies a physical connection to an electric grid; and telephony entails ownership of a mobile phone or landline. For water, sanitation and electricity, we can rely on existing and compiled data sets. The water and sanitation infrastructure indicators are taken from the World Development Indicators (WDI) (World Bank, 2014). For electricity access, we use a compilation of sources, including the WDI, generated for the Global Energy Assessment (GEA, 2012). ${ }^{1}$ For telephony, we use data from the International Telecommunications Union (ITU), which provides landline penetration for the entire period but mobile phone penetration only from 2000 onward (ITU, 2014). We construct a new dataset on telephony access out of available data for (household) access to fixed lines and mobile phones. Comparing the separate data sets, we take access to mobile phones as soon as it exceeds access rates for fixed lines, and interpolate missing values. We consider this approach to be robust and to be a rather conservative estimate of telephony access. We interpolate between years for the infrastructure indicators, since data are sparse for many countries, and infrastructure access levels typically trend only upward. ${ }^{2}$

\footnotetext{
${ }^{1}$ www.globalenergyassessment.org

${ }^{2}$ Wars or natural disasters may lead to loss of infrastructure, which would reduce access levels. However, we assume that ignoring these cases would have a negligible impact on the integrity of the overall data.
} 


\subsection{Patterns of infrastructure access}

Access to different infrastructure services is distributed unevenly across different countries, regions within countries, and income groups. Generally, we find that access to infrastructure increases with income (Figure 1). However, the degree of income dependence varies across the different infrastructure services. While water access is generally available to a broad range of the population at low income levels, electricity and telephony show higher levels of access only at higher levels of income. Access to sanitation, even though correlated with income, seems to be distributed more widely. In addition to pure income effects, Figure 1 also indicates more general regional differences. While African countries tend to have lower access levels, Asian and Latin American countries seem to provide higher access levels at comparable income levels.
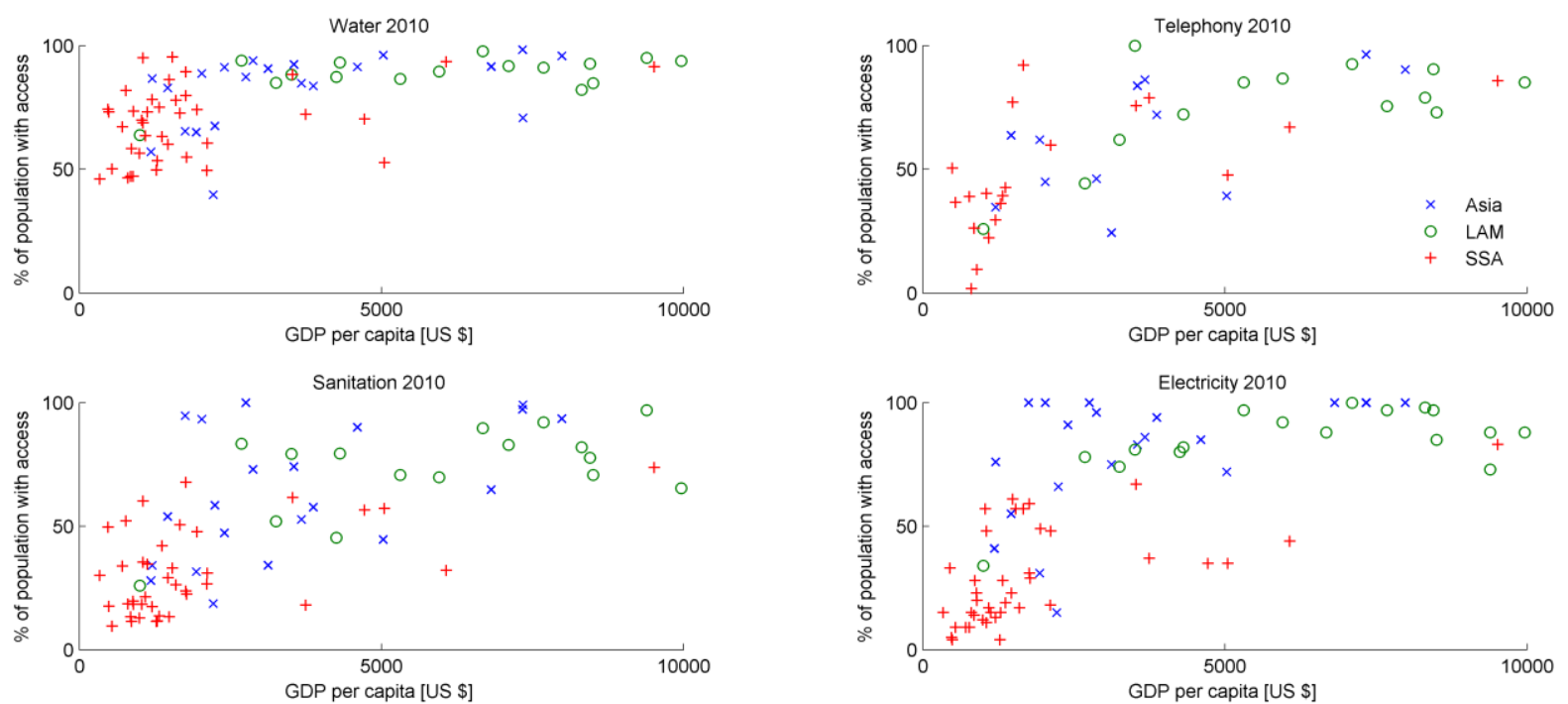

Figure 1: Access rates in 2010 for different sectors and regions. Sub-Saharan African Countries are coloured red (plusses), Latin American Countries green (circles), Asian countries blue (crosses).

Figure 2 shows the temporal evolution of access rates to electricity, water, and sanitation in urban and rural areas separately by region: Africa (panel a), Latin America (panel b), Asia (panel c), and Europe (panel d). In all cases rural households exhibit lower access rates than urban households. With the exception of Africa, urban households show access rates above $80 \%$ in all regions and categories. 
Furthermore, for Africa, Latin America, and Asia, all indicators show an upward trend and convergence (a decreasing gap between the highest and lowest values within one region).

(a) Africa

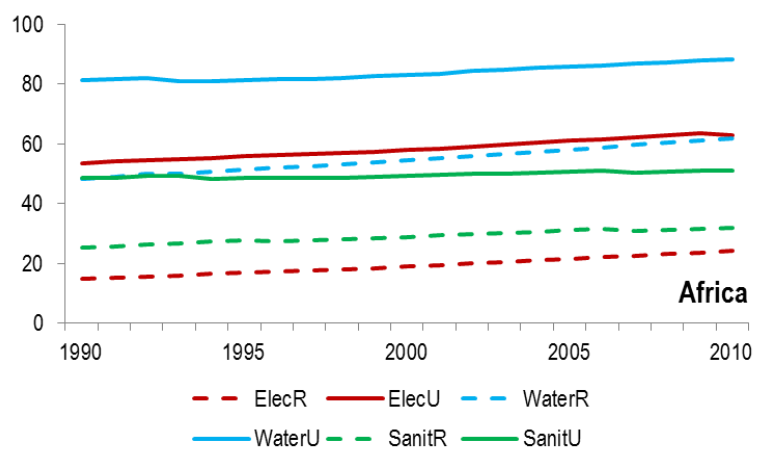

(c) Asia

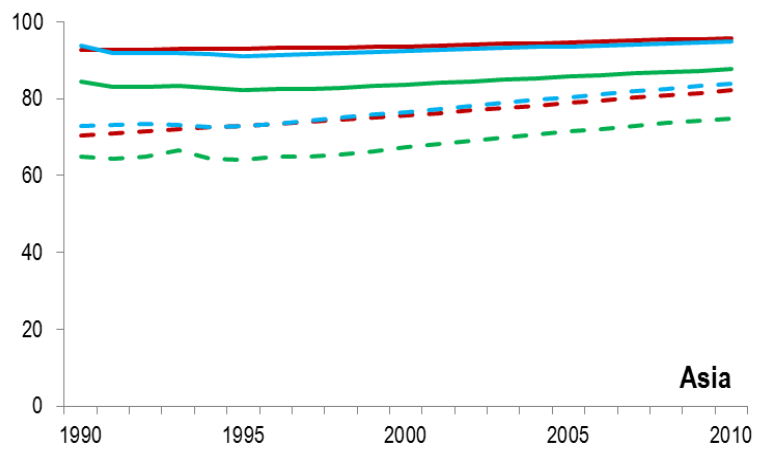

(b) Latin America

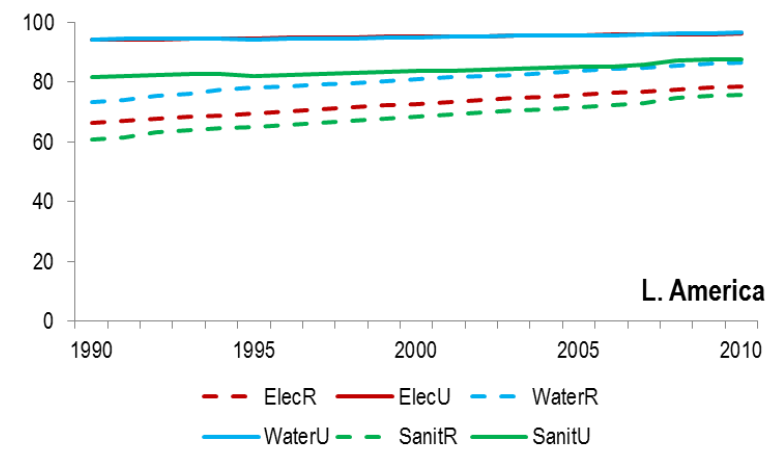

(d) Europe

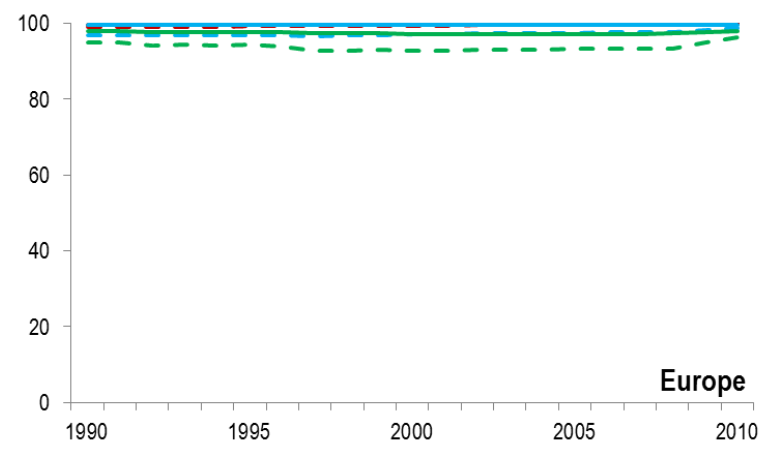

Figure 2: Access to water, electricity, and sanitations for urban and rural households in per cent in Africa (panel a), Latin America (panel b), Asia (panel c), and Europe (panel d). Urban access rates shown as solid lines, rural as dashed. Colors differentiate infrastructure types.

In all regions, including Europe, a general hierarchy for different infrastructure services emerges. The highest level of access is always to water followed by access to electricity, both in rural and urban areas (with the exception of rural access rates in Africa). In all regions except Africa, the lowest access rates are found for rural sanitation. Africa stands out as an exception in terms of the priorities given to different infrastructure sectors. Rural electricity access is even lower than rural sanitation access. Further, the rate of water access is much higher than for electricity access, while in Latin America and Asia the difference is much smaller (and even negligible for urban areas). Among developing regions, Latin America and Asia show a convergence in access rates over time, while in Africa the extent of convergence is almost negligible. 
Figure 3 clusters available data on infrastructure according to access levels for different infrastructure services. We divide all available data (1960 - 2011) into five income groups and look at median levels (squares), as well as the $25^{\text {th }}$ to $75^{\text {th }}$ percentile ranges (coloured) ${ }^{3}$. Whiskers indicate maximum and minimum values. Generally, results reinforce the hierarchy of infrastructure provision in the process of economic development, with highest access rates for water, and lowest ones for telephony and inbetween values for sanitation and electricity. This observation also holds when looking at the urbanrural divide (see Figure $3 b$ ). It is however interesting that for all income groups there exist outliers, that is, countries that have, at certain points in time, provided significantly higher access rates than the inter-quartile ranges. Those outliers work in both directions; we can find very poor countries that provide nearly full access to infrastructure, but also countries with high and very high income levels that have very low access rates. We note that by looking across the entire panel we partly ignore important technological advancements in the telecommunications sector that in the last years have significantly increased access rates to telephony in many developing countries.

(a) Total access

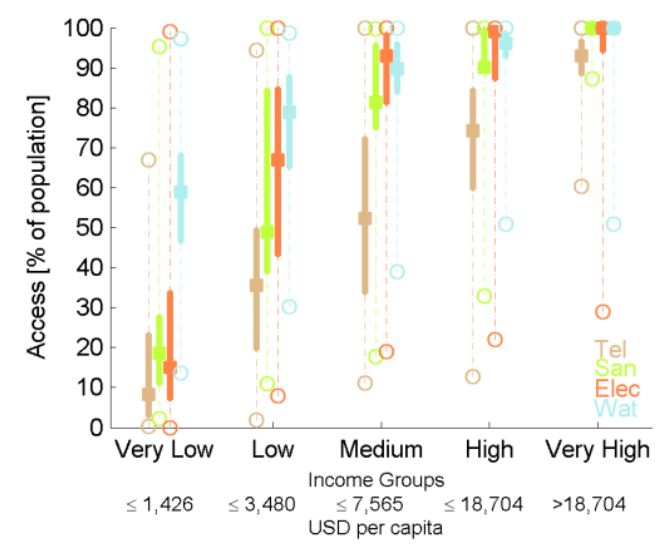

(b) Urban / Rural areas

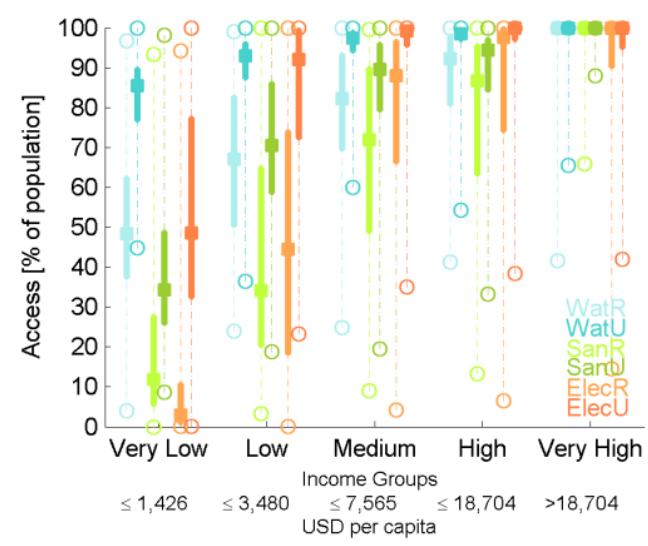

\footnotetext{
${ }^{3}$ The first income quintile covers per capita incomes $<$ USD 1,424, the second $<$ USD 3,484, the third < USD 7,581 , the fourth $<$ USD 18,729 and the fifth $\geq$ USD 18,729. Data are taken from World Bank (2014) and reported in 2005 international dollar PPP.
} 
Figure 3: Access to infrastructure services (left picture total access, right picture divided by rural and urban) across different country income groups. Squares indicate the median, coloured lines indicate the $25^{\text {th }}$ to $75^{\text {th }}$ percentiles and colored dots indicate maxima and minima. Data source: World Bank (2014), ITU (2014), GEA (2012)

\subsection{Outlier analysis}

The analysis shown in Figure 3 defines outliers for every income group, that is, countries that are in the highest (lowest) access quintile in a particular income group. Figure 4 shows outliers in absolute terms. We define "positive" absolute outliers to be countries in the very low income quintile (lower than USD 1,500 per capita) with access rates higher than 75\%. On the other hand, "negative" outliers are countries that are at in the medium income quintile (or higher), with access rates lower than $50 \%$. This analysis reveals an interesting regional pattern.

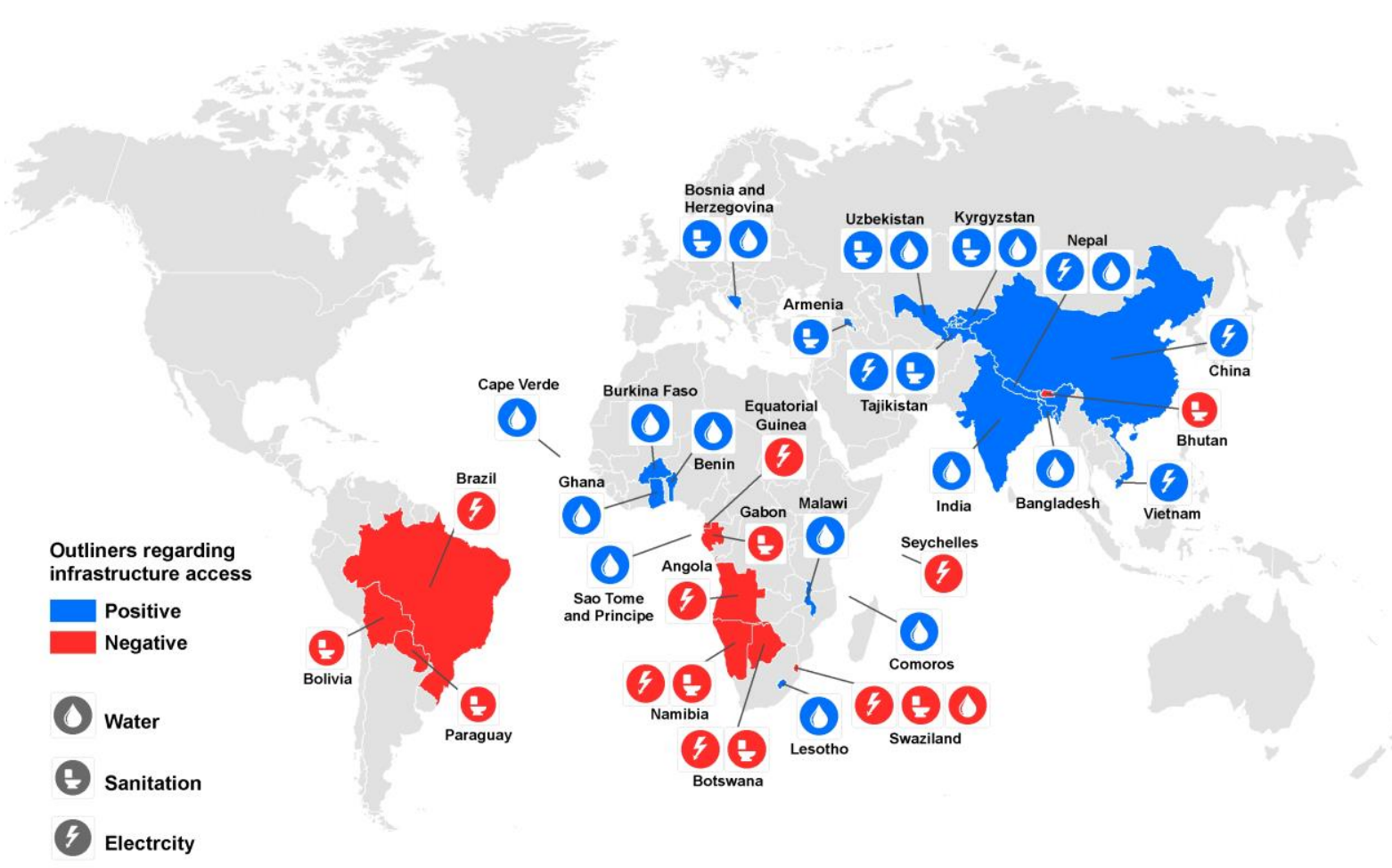

Figure 4: Positive and negative outliers for different infrastructure services. Countries are shown as 'positive outlier' ('negative outlier') if at any available point in time they have shown GDP lower than USD 1,500 (higher than USD 4,000) per capita (PPP, constant 2005 intl. \$) and access rates higher 75\% (lower 50\%).

We mainly find positive outliers for water access in two sets of countries: (a) centrally planned countries (or countries that have formerly been centrally planned such as the Soviet Union or former 
Yugoslavia), and (b) some Sub-Saharan African countries. Countries in the first group may have high infrastructure access due to an increased focus on infrastructure investment under central planning, in combination with declining incomes for several members of the former Soviet Union after its dissolution (with lower incomes and constant level of infrastructure access increasing the likelihood of showing up as an outlier). In the case of Sub-Saharan Africa, given that most of the poorest countries in the world are located there, high access levels may be due to a number of factors. Governments may have given access to water more importance due to its essential nature. Further, expanding access may be easier for water than for other infrastructure services. In addition, it could be the case that development efforts and multilateral cooperation to target water access in Africa have contributed to positive results. Negative outliers are mostly found in Latin America and Africa (for infrastructure other than water). One explanation for this observation could be the extent of resource dependency (measured by a high share of resource rents in GDP) in most of these countries and the possibility of a kind of 'natural resource curse' with regard to infrastructure access. An alternative explanation concerns geographical features, such as a higher share of desert areas and mountain ranges in these countries, which makes it more difficult to provide infrastructure to people.

The observed patterns can also be found when looking at "relative" outliers (based on the top and bottom values of access in each income quintile as shown in Figure 3). Positive relative outliers are mostly located in (formerly) centrally planned countries. In addition, most countries that perform well in one area also do so for others. For example, Armenia, Bangladesh, and Nepal are relative outliers (see Figure 3 and Appendix) in all four service categories. Resource exporters appear as outliers in all categories across all income groups, for example Angola, Bolivia (both medium income), Gabon (high income) as well as Oman and Saudi-Arabia (very high income) ${ }^{4}$.

Our results give rise to several hypotheses and questions regarding determinants of infrastructure access. First, we expect infrastructure access to increase with higher income levels and with increasing

\footnotetext{
${ }^{4}$ We provide a full list of relative outliers in the Appendix.
} 
population density, as reflected by differences across urban and rural regions. Both hypotheses seem plausible. Specifically, higher income can reflect higher investment potential for infrastructure and urban areas often receive priority over rural areas with regard to many development conditions, due to higher population density, concentration of economic activity, and economies of scale, among other reasons.

Other factors may also influence access. Since the lack of infrastructure access is likely concentrated in poor regions, we expect that income inequality in combination with income growth may affect the flow of investment toward improving infrastructure access. Investment may also flow from foreign sources, including both private investment and development aid (see Hausman, Neufeld, and Schreiber (2014) on use of ODA to expand energy access in developing countries).

Finally, institutional capacity and political orientation, among other institutional characteristics, may also reflect the priority placed on expanding access to infrastructure. Results of our data analysis give rise to the hypothesis that "left-leaning" governments might give higher priority to infrastructure access than other.

\section{Data and Methods}

In this section we investigate these relationships described formally, both within and across countries. We use a global panel data set for the period $1990-2010^{5}$. Our main goal is to test the effect of GDP and population density (as a proxy for the rural-urban divide) on infrastructure access. Our analysis is an effort to provide evidence suggestive of the influence of these drivers on infrastructure, rather than to establish causal relationships. That is, we view our results as strong correlations, after controlling for some of primary national macro-economic characteristics. Based on our hypotheses and data availability, we use the following control variables: Gini coefficient for income inequality; foreign direct

\footnotetext{
${ }^{5}$ Data were not available for a longer time period for all infrastructure services.
} 
investment (FDI) and overseas development assistance (ODA), both measured as shares of GDP; and political orientation of country's executive branch.

Even though we considered the urban/rural divide in our descriptive analysis, for the econometric analysis we do not use an urban/rural binary indicator for two main reasons. First, it does not provide the granularity to examine changes over time in poor countries that are largely rural. Second, definitions of "urban" vary widely, such as those applied to India and China. ${ }^{6}$ We instead choose overall population density with respect to arable land only, which more accurately reflects population density in settled areas.

\subsection{Data}

In addition to the infrastructure data described in Section 3, foreign direct investment (FDI) and population density are taken from the WDI (World Bank 2014). We obtain official development assistance (ODA) data from the OECD, which includes sector-specific outflows from OECD to all developing countries together and global outflows to individual countries. We use the latter (global outflows to individual countries), since overall aid to particular countries likely reflects their investments in infrastructure better than global trends in infrastructure investments.

We selected countries with GDP per capita less than USD 25K, since all richer countries have close to 100 percent access. Their inclusion would mask the relationship we aim to explain. Our overall sample includes over 2,800 observations from 154 countries for the period 1990 to 2010 . However, including income inequality and foreign direct investment reduces our sample by an order of magnitude, to 193 observations from 32 countries. Notably, the smaller sample leaves out the bulk of observations from Latin America and Africa, making the share of observations from Asia and Europe 40 percent in the larger sample and 90 percent in the smaller sample. A summary of the data is provided in Table 1.

\footnotetext{
${ }^{6}$ In India, assuming other criteria are met, areas with population density higher than 400 people per $\mathrm{km}^{2}$ classify as urban, while in China population density would have to exceed 1,500 persons per $\mathrm{km}^{2}$, according to the Fifth Census, 2000.
} 
Table 1: Summary statistics and data sources. Variable summaries do not necessarily represent the same set of countries, since data are not available for all indicators for all countries.

\begin{tabular}{|c|c|c|c|c|}
\hline Variable & Data Source & Mean (1990) & $\begin{array}{l}\text { Mean } \\
(2010)\end{array}$ & $\begin{array}{l}\text { Std Dev } \\
(2010)\end{array}$ \\
\hline \multicolumn{5}{|c|}{ Dependent Variables (\%) } \\
\hline Water Access & World Bank (2014) & 80.2 & 87.7 & 15.7 \\
\hline Electricity Access & World Bank (2014); GEA (2012) & 68.7 & 75.2 & 31.4 \\
\hline Sanitation Access & World Bank (2014) & 67.0 & 73.1 & 29.9 \\
\hline Telephony Access & ITU (2014), World Bank (2014) & 41.2(1995) & 81.6 & 16.2 \\
\hline \multicolumn{5}{|c|}{ Independent Variables } \\
\hline $\begin{array}{ll}\text { GDP } & \text { (\$PPP } \\
2005 / \text { cap) } & \end{array}$ & World Bank (2014) & 8,984 & 12,500 & 1,357 \\
\hline $\begin{array}{ll}\text { Pop } & \text { Density } \\
\text { (‘000/km² } & \text { arable) }\end{array}$ & World Bank (2014) & 3,913 & 2,391 & 10,242 \\
\hline $\begin{array}{l}\text { Income Inequality } \\
\text { (Gini) }\end{array}$ & World Bank (2014) & 28.5 & $\begin{array}{l}29.8 \\
(2005)\end{array}$ & $\begin{array}{l}5.1 \\
(2005)\end{array}$ \\
\hline FDI (\% of GDP) & World Bank (2014) & 2.1 (1995) & $\begin{array}{l}13.2 \\
(2005)\end{array}$ & $\begin{array}{l}33.8 \\
(2005)\end{array}$ \\
\hline ODA (\$ mil) & OECD (2017) & 850 & 922 & 1,324 \\
\hline
\end{tabular}

\subsection{Estimation Method}

Infrastructure access levels, our outcome variables, are measured in terms of a percentage of households. This means they are restricted to the unit interval (0 to 1$)$, potentially including both values, and include proportions between them. The existence of such a fractional dependent variable places restrictions on suitable estimation methods. Ordinary linear model estimators do not take into account nonlinearities, such as those related to saturation of access levels at close to 100 percent. Logodds transformations fail at the extreme values (Papke and Wooldridge, 2008). To circumvent this problem, Papke and Wooldridge (1996) propose the fractional logit model, whose application to panel 
data analysis has steadily increased. The structure of our panel permits the inclusion of fixed effects without compromising inference. ${ }^{7}$

A potential issue is reverse causation, as one would not only expect an influence of GDP on infrastructure access, but also an effect of infrastructure on GDP (as analysed, for example, by Calderon and Serven (2014). In our case, this concern may be somewhat mitigated considering that changes in infrastructure access pertain mostly to rural, poor households' access, whose economic activities are likely to be relatively small or fall outside conventional macroeconomic accounting (an exception might be the case of roads, which we do not include in our analysis). Ideally, we would have used an Instrument Variable for GDP as a precaution, but this requires that we have a reliable predictor of GDP, which does not exist in literature. Instead, we conduct sensitivities of our analysis with 1-year and 3year lags on all explanatory variables. This does not entirely guarantee robustness, which is a caveat.

The model specification for explaining "within-country" infrastructure access, $l_{i, t}$, for country $i$ and time $t$ is as follows:

$$
E\left(I_{i, t} \mid \boldsymbol{x}_{i, t}, c_{i}\right)=\boldsymbol{\phi}\left(\boldsymbol{x}_{i, t} \beta+c_{i}\right)
$$

The expectation of the conditional mean of $l_{i, t}$ is given by a cumulative distribution function $\varphi$, which is a function of a vector of explanatory variables, $\boldsymbol{x}_{i, t}$, described above, and a fixed effect, $c_{i}$, for countries (or regions). The coefficients are expressed in exponential form and therefore represent the proportionate change in the outcome relative to a unit change in the covariate.

\footnotetext{
${ }^{7}$ The inclusion of fixed effects for cross-sectional units (countries or regions in our case) requires that the number of periods $T$ is not restricted, or small, relative to the number of cross-sectional units $N$, because the estimation is not consistent for $\mathrm{N} \rightarrow \infty$. However, our $N$ and $T$ are of the same order of magnitude, and consistent in proportion to other studies that have successfully applied this technique (Hausman and Leonard, 1997 cited in Papke and Wooldridge, 2008).
} 
To assess the drivers of infrastructure access level differences across countries, we set up a "betweencountry" model by averaging all outcome variables and covariates over time for each country, and estimating the same fractional logit model.

\section{Results and Discussion}

This section describes and discusses the key results from the econometric estimates described in section 4.

\subsection{Results}

Table 2 below shows the results of the within country panel estimation. Notably, all the results shown were reproduced (with minor differences in the magnitude of coefficients) with 1-year and 3-year lags on all explanatory variables, thereby addressing endogeneity concerns to the extent possible (see Appendix Table S15-Table S18). In order to keep the analysis tractable, results for each dependent variable are only provided for different specifications when they are not close to identical (for full results see Appendix). Both GDP and population density are important drivers, though GDP is more robust and influential. Goodness-of-fit (chi-square) tests show that our covariates (notably GDP and population density) indeed improve the prediction of access variables as compared to only country effects. However, the predictive power is stronger at higher access levels, generally above 70 percent. Our explanatory variables do not explain the wide range of access levels observed in poor countries, namely those with GDP less than PPP\$4K per capita, except in the case of telephony, where the predictive power extends to lower levels of access (see Appendix). This is primarily due to the high levels of access achieved among countries with relatively low GDPs, which distort the typical "saturation curve".

The magnitude of the effects can be interpreted from the coefficients in Tables 2 and 3, which show in exponentiated form the Relative Proportions Ratio from a unit change in the relevant variable. In general, a thousand dollar per capita increase in GDP (standard deviation of $\$ 4 K$ ) is associated with an 11 to 78 percent mean increase in access, the lower end being for sanitation, and the higher end for 
telephony. An increase in population density of a thousand persons per $\mathrm{km}^{2}$ is associated with a 52 percent increase in water access, a three-fold increase in electricity access, and a 3.5 fold increase in sanitation access levels (note: the standard deviation for population density is $400 / \mathrm{km}^{2}$ ) when controlling for income inequality and FDI. If we exclude income inequality and FDI (results reported in Table 2) the sensitivity is far lower, at 1 to 2 percent for sanitation and water access, and 28 percent for telephony. This difference may reflect a different relationship between access and population density in Asia and Europe than in Latin America and Africa, because the drop in sample size from including FDI and income inequality predominantly occurs by excluding countries in Latin America and Africa (for which no data on FDI or inequality are available). However, we do not have a particular hypothesis for why this might be the case.

Due to the strong correlation between GDP and population density (roughly 0.5 in the pooled sample), the related effects on access levels are not easily disentangled. However, the difference in their relative influence on sectors is more robust, and therefore noteworthy. For instance, the influence of GDP is greatest for telephony and least for sanitation. Increases in population density are associated with better access for all sectors except for urban water. Both GDP and population density influence rural access more than they do urban access levels for all sectors (Table 3).

Table 2: Infrastructure access drivers within countries.

\begin{tabular}{|c|c|c|c|c|c|c|}
\hline Dep.Var (DV): & $\begin{array}{l}\text { Water } \\
\text { (1) }\end{array}$ & $\begin{array}{l}\text { Water } \\
(2)\end{array}$ & $\begin{array}{l}\text { Sanitation } \\
\text { (1) }\end{array}$ & $\begin{array}{l}\text { Sanitation } \\
\text { (2) }\end{array}$ & Telephony & $\begin{array}{c}\text { Electricity } \\
\text { (1) }\end{array}$ \\
\hline \multicolumn{7}{|l|}{ Access (\% pop) } \\
\hline $\begin{array}{l}\text { GDP per cap } \\
\text { ('000s, PPP, \$2005) }\end{array}$ & $\begin{array}{r}1.45 * * * \\
(9.73)\end{array}$ & $\begin{array}{r}1.19 * * * \\
(17.02)\end{array}$ & $\begin{array}{r}1.11 * * * \\
(3.75)\end{array}$ & $\begin{array}{r}1.16 * * * \\
(17.81)\end{array}$ & $\begin{array}{r}1.78^{* * *} \\
(11.71)\end{array}$ & $\begin{array}{l}1.47^{* * *} \\
(6.31)\end{array}$ \\
\hline $\begin{array}{l}\text { Pop Density } \\
\text { ('000s, per arable km²) }\end{array}$ & $\begin{array}{r}1.52 * * * \\
(3.03)\end{array}$ & $\begin{array}{r}1.02^{* *} \\
(2.18)\end{array}$ & $\begin{array}{r}3.47^{* * *} \\
(5.50)\end{array}$ & $\begin{array}{r}1.01 * * * \\
(3.48)\end{array}$ & $\begin{array}{r}1.28 * * * \\
(3.19)\end{array}$ & $\begin{array}{l}3.08^{* * *} \\
(4.11)\end{array}$ \\
\hline $\begin{array}{l}\text { Income inequality } \\
\text { (Gini, } 1 \text { to } 100 \text { ) }\end{array}$ & $\begin{array}{r}1.01 \\
(1.06)\end{array}$ & & $\begin{array}{c}1.01 \\
(1.32)\end{array}$ & & & $\begin{array}{l}1.03^{* * *} \\
(2.93)\end{array}$ \\
\hline $\begin{array}{l}\text { FDI } \\
\text { (\% GDP) }\end{array}$ & $\begin{array}{l}0.98^{*} \\
(1.96)\end{array}$ & & $\begin{array}{r}1.00 \\
(0.12)\end{array}$ & & & $\begin{array}{c}1.00 \\
(0.36)\end{array}$ \\
\hline No Obs & 177 & 2825 & 182 & 2789 & 722 & 193 \\
\hline Asia/Europe Share & $89 \%$ & $40 \%$ & $89 \%$ & $40 \%$ & $40 \%$ & $90 \%$ \\
\hline & & & 15 & & & \\
\hline
\end{tabular}




$$
* p<0.1 ; * * p<0.05 ; * * * p<0.01
$$

Coefficients in exponentiated form, showing average proportionate change in the DV from a unit change in covariates. Values $<1$ reflect an inverse relationship. Figures in parenthesis are z-stats. Note: (1) suffix refers to models that include FDI and Gini, which reduces the sample size due to limited data availability.

Table 3: Infrastructure access drivers in urban and rural areas within countries (models including income inequality and FDI are displayed where significant).

\begin{tabular}{|c|c|c|c|c|c|c|}
\hline \multirow{2}{*}{$\begin{array}{l}\text { Dep.Var (DV): } \\
\text { Access (\% pop) }\end{array}$} & \multicolumn{2}{|c|}{ Water } & \multicolumn{2}{|c|}{ Sanitation } & \multicolumn{2}{|c|}{ Electricity } \\
\hline & Rural & Urban & Rural & Urban & Rural & Urban \\
\hline $\begin{array}{l}\text { GDP per cap } \\
\text { (000s, PPP, \$2005) }\end{array}$ & $\begin{array}{r}1.44 * * * \\
(10.40)\end{array}$ & $\begin{array}{r}1.36 * * * \\
(7.92)\end{array}$ & $\begin{array}{r}1.18 * * * \\
(18.56)\end{array}$ & $\begin{array}{r}1.09 * * * \\
(13.70)\end{array}$ & $\begin{array}{r}1.36 * * * \\
(4.98)\end{array}$ & $\begin{array}{r}1.24 * \\
(1.83)\end{array}$ \\
\hline $\begin{array}{l}\text { Pop Density } \\
\text { (000s, per arable } \mathrm{km}^{2} \text { ) }\end{array}$ & $\begin{array}{r}1.75^{* * *} \\
(3.19)\end{array}$ & $\begin{array}{r}0.72 * * * \\
(3.19)\end{array}$ & $\begin{array}{r}1.00 \\
(0.37)\end{array}$ & $\begin{array}{r}1.01^{* *} \\
(2.45)\end{array}$ & $\begin{array}{r}3.94 * * * \\
(3.66)\end{array}$ & $\begin{array}{c}3.43 * * * \\
(5.89)\end{array}$ \\
\hline $\begin{array}{l}\text { Income Inequality } \\
\text { (Gini, } 1 \text { to } 100)\end{array}$ & $\begin{array}{r}1.01 \\
(0.99)\end{array}$ & $\begin{array}{r}1.01 \\
(1.32)\end{array}$ & & & $\begin{array}{r}1.02 * * \\
(2.39)\end{array}$ & $\begin{array}{c}1.02 \\
(1.34)\end{array}$ \\
\hline $\begin{array}{l}\text { FDI } \\
\text { (\% GDP) }\end{array}$ & $\begin{array}{r}0.98 * * \\
(2.15)\end{array}$ & $\begin{array}{r}0.96 * * * \\
(3.09)\end{array}$ & & & $\begin{array}{r}0.99 \\
(0.75)\end{array}$ & $\begin{array}{c}1.00 \\
(0.26)\end{array}$ \\
\hline No Obs & 177 & 193 & 2805 & 2833 & 193 & 193 \\
\hline Asia/Europe Share & $90 \%$ & $90 \%$ & $40 \%$ & $40 \%$ & $90 \%$ & $90 \%$ \\
\hline
\end{tabular}
Values $<1$ reflect an inverse relationship. Figures in parenthesis are z-stats.

Income inequality has a surprisingly negligible but positive effect on all access indicators. In the case of rural electricity, increasing inequality by one point in the Gini (standard deviation of 10 points) leads to an increase in expected access of 3 percent. FDI has a small but negative effect, which is significant in the case of urban and rural water access. A percentage point change in FDI (standard deviation of 3.5 percent) leads to a reduction in expected access levels of 2 percent for water. A possible explanation for this observation could be that poorer countries, which on average display lower access rates, also receive less FDI (as a share of GDP).

The drivers that explain differences in access levels between countries differ from drivers of withincountry trends (Table 4). GDP has a strong positive influence, though the difference is more pronounced for electricity and less so for telephony. However, population density is either marginally 
significant, or insignificant. Higher income inequality is associated with lower access levels, but by a small margin ( 4 to 8 percent reduction in access for a unit increase in the Gini).

Table 4: Infrastructure access drivers among countries

\begin{tabular}{|c|c|c|c|c|c|c|}
\hline Dep.Var (DV): & $\begin{array}{l}\text { Water } \\
\text { (1) }\end{array}$ & $\begin{array}{l}\text { Water } \\
(2)\end{array}$ & Sanitation & $\begin{array}{l}\text { Electricity } \\
\text { (1) }\end{array}$ & $\begin{array}{l}\text { Electricity } \\
\text { (2) }\end{array}$ & Telephony \\
\hline \multicolumn{7}{|l|}{ Access (\% pop) } \\
\hline $\begin{array}{l}\text { GDP per cap } \\
\text { ('000s, PPP, \$2005) }\end{array}$ & $\begin{array}{r}1.27 * * * \\
(5.68)\end{array}$ & $\begin{array}{r}1.25 * * * \\
(6.57)\end{array}$ & $\begin{array}{l}1.32 * * * \\
(8.01)\end{array}$ & $\begin{array}{c}1.57 * * * \\
(3.62)\end{array}$ & $\begin{array}{r}1.35 * * * \\
(4.41)\end{array}$ & $\begin{array}{r}1.18^{* * * *} \\
(9.60)\end{array}$ \\
\hline $\begin{array}{l}\text { Pop Density } \\
\text { ('000s, per arable } \mathrm{km}^{2} \text { ) }\end{array}$ & $\begin{array}{r}1.03 \\
(0.11)\end{array}$ & $\begin{array}{r}1.01 * * * \\
(3.40)\end{array}$ & $\begin{array}{l}1.01^{* * *} \\
(4.44)\end{array}$ & $\begin{array}{c}0.76 \\
(0.79)\end{array}$ & $\begin{array}{r}0.99 \\
(0.95)\end{array}$ & $\begin{array}{r}1.00 \\
(0.39)\end{array}$ \\
\hline $\begin{array}{l}\text { Income inequality } \\
\text { (Gini, } 1 \text { to } 100 \text { ) }\end{array}$ & $\begin{array}{r}0.96 * * \\
(2.11)\end{array}$ & & & $\begin{array}{c}0.93 * * * \\
(3.33)\end{array}$ & & \\
\hline $\begin{array}{l}\text { FDI } \\
\text { (\% GDP) }\end{array}$ & $\begin{array}{r}1.07 \\
(0.89)\end{array}$ & & & $\begin{array}{l}1.34 * * \\
(2.09)\end{array}$ & & \\
\hline No Obs & 28 & 145 & 145 & 29 & 146 & 122 \\
\hline $\begin{array}{l}\text { Coefficients in exponer } \\
\text { covariates. Values }<1 \text { refl } \\
\text { models that inclu }\end{array}$ & $\begin{array}{l}\text { ated form, } \\
\text { an invers } \\
\text { FDI and }\end{array}$ & $\begin{array}{l}* p<0.1 ; * \\
\text { howing ave } \\
\text { relationshi } \\
\text { i, which re }\end{array}$ & $\begin{array}{l}<0.05 ; * * * p<0 \\
\text { e proportionat } \\
\text { igures in parer } \\
\text { es the sample }\end{array}$ & $\begin{array}{l}\text { change in the } \\
\text { esis are z-sta } \\
\text { e due to limi }\end{array}$ & $\begin{array}{l}\text { V from a un } \\
\text { Note: (1) st } \\
\text { d data availa }\end{array}$ & $\begin{array}{l}\text { change in } \\
\text { ix refers to } \\
\text { lity. }\end{array}$ \\
\hline
\end{tabular}

\subsection{Discussion}

The quantitative analysis validates our hypotheses and provides evidence of other intuitively appealing drivers of infrastructure service access. It is not surprising that GDP per capita is associated with higher access levels for all indicators, since it reflects the economic means to provide the associated infrastructure. The findings on population density suggest that, ceteris paribus, countries with higher population density do not have better access levels. However, growing population density within countries leads to improved access levels, particularly in rural areas. This may reflect spillovers in infrastructure provision from urban areas outward. Those with improved access in rural areas would presumably lie in peri-urban areas. This would be worth testing with country studies (see e.g. JiminezRedal et al. (2014) for the case of water connections in peri-urban Maputo in Mozambique).

The findings for income inequality are also intuitively appealing. Since income inequality evolves slowly (the within-country standard deviation is just 2 percentage points in our two-decade timeframe), it is 
unsurprising that improved access is not explained by changes in income inequality. However, countries with lower income inequality tend to provide a larger share of the population with access. This may reflect different political priorities that manifest both in policies that redistribute income and those that expand infrastructure access in poor areas. Alternatively, it may reflect economic capacities, whereby more equal societies have more people with the ability to afford access.

Previous studies have highlighted that political factors are crucial for infrastructure investment, for instance as a tool to promote rent-seeking (Keefer and Knack, 2007) and to ensure voters' support in elections (Castells and Sole-Olle, 2005). We have attempted to account for political factors by including the political orientation indicator from the World Bank's Database of Political Institutions (DPI) into the regression analysis. However, resulting sample sizes turned out to be too small, and the results were not robust. For results between countries, the coefficients were not significant. We therefore decided not to draw on these results. The lack of data on governance and policy indicators, particularly in developing countries, affects our ability to conduct a more detailed empirical analyses.

Another data-driven limitation of this analysis is that infrastructure access indicators do not reflect actual service conditions, such as reliability and quality of service. For instance, electricity access levels in India belie the (fewer) number of people who receive a reasonable number of hours of service (Rao, 2013). As another example, the World Bank data on improved water sources do not reflect the distance of the improved source. A household with an in-house connection and one requiring walking a fair distance to a tube well would be treated equivalent in the data set, despite the significant difference in access convenience.

\section{Conclusions}

This paper is, to our knowledge, the first to provide an overview of global trends in access to infrastructure services that are essential for human development, namely water, sanitation, electricity, and telephony. Our analysis yields the following insights. First, even though our results confirm the well-known correlation between per-capita GDP and access rates, access to infrastructure services 
varies widely, even for countries with comparable per-capita incomes. Our empirical analysis suggests that at least some of these variations may be explained by differences in population density. Second, for all infrastructures under consideration, access levels are markedly higher for urban than for rural areas, which suggests that the former are given priority over the latter in infrastructure build-up. Third, our results suggest a kind of "sequencing" of infrastructure in the process of economic development, with access to water coming first, followed by access to sanitation, electricity, and telephony (see Figure 3). Regarding the latter it should be noted that these results build on a full panel from 1960 to 2011; hence positive effects on access rates from increasingly available mobile telephony in the last decade are not fully regarded.

Our results imply that costs to close gaps in infrastructure services might be lower than expected in static analyses given economic growth and urbanization patterns in developing countries. They can assist policy making by developing plausible future scenarios of access gaps, which will be crucial to determine investment needs for achieving various important aspects of the sustainable development goals ${ }^{8}$. As we have highlighted, due to data limitations, our analysis should best be regarded as a first step toward identifying trends and drivers of infrastructure access. Besides improving the quality of data, future research could analyse other service infrastructures, such as those related to health, or transportation. It should be noted that using aggregated infrastructure data might mask important distinctions, already at the national level. Therefore, we believe that case studies on infrastructure policies in a range of countries are required in order to gain a better understanding of what factors determine whether such policies succeed in expanding access to basic services.

\section{Acknowledgements}

We are grateful for helpful comments by seminar participants at the International Energy Workshop 2014, at MCC, as well as by Jörg Peters, Nicolas Koch, Sabine Fuss and Ottmar Edenhofer. We thank Ulf Weddige and Claudine Chen for supporting us with creating the maps. We thank Mia Burger for

\footnotetext{
${ }^{8}$ In a similar spirit, Bazilian et al. (2012) develop energy access scenarios for Sub-Saharan Africa.
} 
excellent research assistance. NDR acknowledges funding provided by the European Research Council Starting Grant ERC-StG-2014, Contract number 637462 (Decent Living Energy).

\section{References}

Agenor, P.-R., and Moreno-Dodson, B. (2006). Public infrastructure and growth : new channels and policy implications (Policy Research Working Paper Series No. 4064). The World Bank. Retrieved from http://ideas.repec.org/p/wbk/wbrwps/4064.html

Aschauer, D. A. (1989). Is public expenditure productive? Journal of Monetary Economics, 23(2), 177200.

Bazilian, M., Nussbaumer, P., Rogner, H.-H., Brew-Hammond, A., Foster, V., Pachauri, S., ... Kammen, D. M. (2012). Energy access scenarios to 2030 for the power sector in sub-Saharan Africa. Utilities Policy, 20(1), 1-16. https://doi.org/http://dx.doi.org/10.1016/j.jup.2011.11.002

Birdsall, N., and Nellis, J. (2003). Winners and Losers: Assessing the Distributional Impact of Privatization. World Development, 31(10), 1617-1633.

Calderon, C. A., and Serven, L. (2014). The Effects of Infrastructure Development on Growth and Income Distribution. Annals of Economics and Finance, 15(2), 521-534.

Castells, A., and Sole-Olle, A. (2005). The regional allocation of infrastructure investment: The role of equity, efficiency and political factors. European Economic Review, 49(5), 1165-1205.

Cohen, J. P., and Paul, C. J. M. (2004). Public Infrastructure Investment, Interstate Spatial Spillovers, and Manufacturing Costs. The Review of Economics and Statistics, 86(2), 551-560.

Demetriades, P. O., and Mamuneas, T. P. (2000). Intertemporal Output and Employment Effects of Public Infrastructure Capital: Evidence from 12 OECD Economics. Economic Journal, 110(465), 687-712.

Dinkelman, T. (2011). The Effects of Rural Electrification on Employment: New Evidence from South Africa. American Economic Review, 101(7), 3078-3108.

Duflo, E., and Pande, R. (2007). Dams. The Quarterly Journal of Economics, 122(2), 601-646. 
Estache, A., and Fay, M. (2007). Current debates on infrastructure policy (Vol. 4410). World Bank Publications. Retrieved from http://books.google.com/books?hl=enandlr=andid=nmhDOkLkWylCandoi=fndandpg=PA1an ddq $=\% 22$ the+last $+20+y e a r s .+$ This + has + resulted+in+an+unfortunate+slowdown+in+much\%22+\%22was+that+the+private+sector+was+going+to+take+over+these+serv ices,+leaving+only\%22+andots=n_W7Psn54handsig=AOeRdKHfVZADQ2z1BTgcTR4CD_g

Fukuda-Parr, S. (2012). Should global goal setting continue, and how, in the post-2015 era? (UN DESA Working Paper No. 117). Retrieved from www.un.org/esa/desa/papers/2012/wp117_2012.pdf

Galiani, S., Gertler, P., and Schargrodsky, E. (2005). Water for Life: The Impact of the Privatization of Water Services on Child Mortality. Journal of Political Economy, 113(1), 83-120.

GEA. (2012). Global Energy Assessment - Toward a Sustainable Future. Cambridge University Press, Cambridge, UK and New York, NY, USA and the International Institute for Applied Systems Analysis, Laxenburg, Austria. Retrieved from www.globalenergyassessment.org

Gramlich, E. M. (1994). Infrastructure Investment: A Review Essay. Journal of Economic Literature, 32(3), 1176-96.

Griggs, D., Stafford-Smith, M., Gaffney, O., Rockström, J., Öhman, M. C., Shyamsundar, P., ... Noble, I. (2013). Policy: Sustainable development goals for people and planet. Nature, 495(7441), 305-307.

Haughwout, A. F. (2002). Public infrastructure investments, productivity and welfare in fixed geographic areas. Journal of Public Economics, 83(3), 405-428.

Hausman, W. J., Neufeld, J. L., and Schreiber, T. (2014). Multilateral and bilateral aid policies and trends in the allocation of electrification aid, 1970-2001. Utilities Policy, 29, 54-62. https://doi.org/10.1016/j.jup.2013.12.004

Irmen, A., and Kuehnel, J. (2009). Productive Government Expenditure And Economic Growth. Journal of Economic Surveys, 23(4), 692-733. 
ITU. (2014). World Telecommunication/ICT Indicators database, 18th Edition. Retrieved from http://www.itu.int/en/ITU-D/Statistics/Pages/publications/wtid.aspx

Jakob, M., and Edenhofer, O. (2014). Green Growth, Degrowth, and the Commons. Oxford Review of Economic Policy, 30(3).

Jimenez-Redal, R., Parker, A., and Jeffrey, P. (2014). Factors influencing the uptake of household water connections in peri-urban Maputo, Mozambique. Utilities Policy, 28, 22-27. https://doi.org/10.1016/j.jup.2013.11.003

Keefer, P., and Knack, S. (2007). Boondoggles, Rent-Seeking, and Political Checks and Balances: Public Investment under Unaccountable Governments. The Review of Economics and Statistics, 89(3), 566-572.

OECD (2017). Detailed aid statistics: Official and private flows. OECD International Development Statistics (database).DOI: http://dx.doi.org/10.1787/data-00072-en

Onyeji, I., Bazilian, M., and Nussbaumer, P. (2012). Contextualizing electricity access in sub-Saharan Africa. Energy for Sustainable Development, 16(4), 520-527. https://doi.org/10.1016/j.esd.2012.08.007

Papke, L. E., and Wooldridge, J. M. (1996). Econometric methods for fractional response variables with an application to 401 (K) plan participation rates. Journal of Applied Econometrics, 11, $619-632$.

Papke, L. E., and Wooldridge, J. M. (2008). Panel data methods for fractional response variables with an application to test pass rates. Journal of Econometrics, 145(1), 121-133.

Peters, J., and Sievert, M. (2016). Impacts of rural electrification revisited-the African context. Journal of Development Effectiveness, 8(3), 327-345.

Rao, N. D. (2013). Does (better) electricity supply boost household enterprise income in India? Energy Policy, 57, 532-541.

Ravallion, M. (2011). On multidimensional indices of poverty. The Journal of Economic Inequality, 9(2), 235-248. https://doi.org/10.1007/s10888-011-9173-4 
Reinert, K. A. (2011). No small hope: the basic goods imperative. Review of Social Economy, 69(1), $55-76$.

Robinson, J. A., and Torvik, R. (2005). White elephants. Journal of Public Economics, 89(2-3), 197210.

Romp, W., and Haan, J. de. (2007). Public Capital and Economic Growth: A Critical Survey. Perspektiven Der Wirtschaftspolitik, 8(s1), 6-52.

Straub, S. (2011). Infrastructure and Development: A Critical Appraisal of the Macro-level Literature. Journal of Development Studies, 47(5), 683-708.

Tsui, K. (2002). Multidimensional poverty indices. Social Choice and Welfare, 19(1), 69-93.

UN. United Nations Millennium Declaration (2000). Retrieved from http://www.un.org/millennium/declaration/ares552e.htm World Bank. (2014). World Development Indicators. Retrieved from http://databank.worldbank.org/data/views/variableselection/selectvariables.aspx?source=w orld-development-indicators 
Access to infrastructure services: global trends and drivers

Supplementary Information 


\section{I) Positive and negative relative outliers}

\begin{tabular}{|c|c|c|c|c|c|c|c|c|}
\hline Very low & Electricity & & Sanitation & & Water & & Telephony & \\
\hline \multirow{22}{*}{$\begin{array}{l}100-\text { ca. } \\
1500 \$\end{array}$} & Afghanistan & 41 & Afghanistan & 28.25 & Bangladesh & 79.2 & Bangladesh & 37 \\
\hline & Bangladesh & 55 & Bangladesh & 44.85 & Benin & 72.4 & Benin & 33.4 \\
\hline & Cape Verde & 58 & $\begin{array}{ll}\text { Bosnia and } \\
\text { Herzegovina }\end{array}$ & 95.3 & $\begin{array}{l}\text { Bosnia and } \\
\text { Herzegovina }\end{array}$ & 97.3 & $\begin{array}{l}\text { Burkina } \\
\text { Faso }\end{array}$ & 26.8 \\
\hline & China & 77 & Burundi & 45.8 & $\begin{array}{l}\text { Burkina } \\
\text { Faso }\end{array}$ & 74.6 & Ghana & 47 \\
\hline & Comoros & 45 & Cape Verde & 35.5 & Burundi & 72.05 & Haiti & 25 \\
\hline & Ghana & 53 & $\begin{array}{ll}\text { Central African } \\
\text { Republic }\end{array}$ & 33.7 & Cape Verde & 80.4 & $\begin{array}{l}\text { Kyrgyz } \\
\text { Republic }\end{array}$ & 30.7 \\
\hline & Guinea-Bissau & 54 & China & 28 & China & 69.6 & Liberia & 36.6 \\
\hline & India & 51 & Comoros & 34.2 & Comoros & 92 & Madagascar & 25.8 \\
\hline & Lao PDR & 49 & Congo Dem. Rep. & 29.65 & Ghana & 77.5 & Malawi & 36.3 \\
\hline & Nepal & 73 & Kenya & 28.1 & Guinea & 71.7 & Nepal & 31.2 \\
\hline & Nigeria & 43.5 & Kyrgyz Republic & 93.1 & $\begin{array}{l}\text { Guinea- } \\
\text { Bissau }\end{array}$ & 70.8 & Niger & 33.9 \\
\hline & Senegal & 37 & Lao PDR & 31 & India & 72.9 & Rwanda & 33.5 \\
\hline & Tajikistan & 99 & Malawi & 45.85 & $\begin{array}{l}\text { Kyrgyz } \\
\text { Republic }\end{array}$ & 77.9 & Senegal & 41 \\
\hline & Timor-Leste & 38 & Nepal & 32.15 & Lesotho & 79.7 & $\begin{array}{l}\text { Sierra } \\
\text { Leone }\end{array}$ & 28 \\
\hline & Vietnam & 88 & Rwanda & 47.95 & Liberia & 71.9 & Tanzania & 30.1 \\
\hline & & & $\begin{array}{l}\text { Sao Tome and } \\
\text { Principe }\end{array}$ & 29.4 & Malawi & 76.95 & Zambia & 32.9 \\
\hline & & & Senegal & 39.15 & Nepal & 78.9 & & \\
\hline & & & Tajikistan & 89.75 & Rwanda & 68.7 & & \\
\hline & & & Timor-Leste & 37.8 & $\begin{array}{l}\text { Sao Tome } \\
\text { and Principe }\end{array}$ & 84.4 & & \\
\hline & & & Uganda & 31.7 & Timor-Leste & 69.1 & & \\
\hline & & & Vietnam & 43.4 & Uganda & 72.35 & & \\
\hline & & & Zambia & 41.25 & Vietnam & 70.2 & & \\
\hline
\end{tabular}




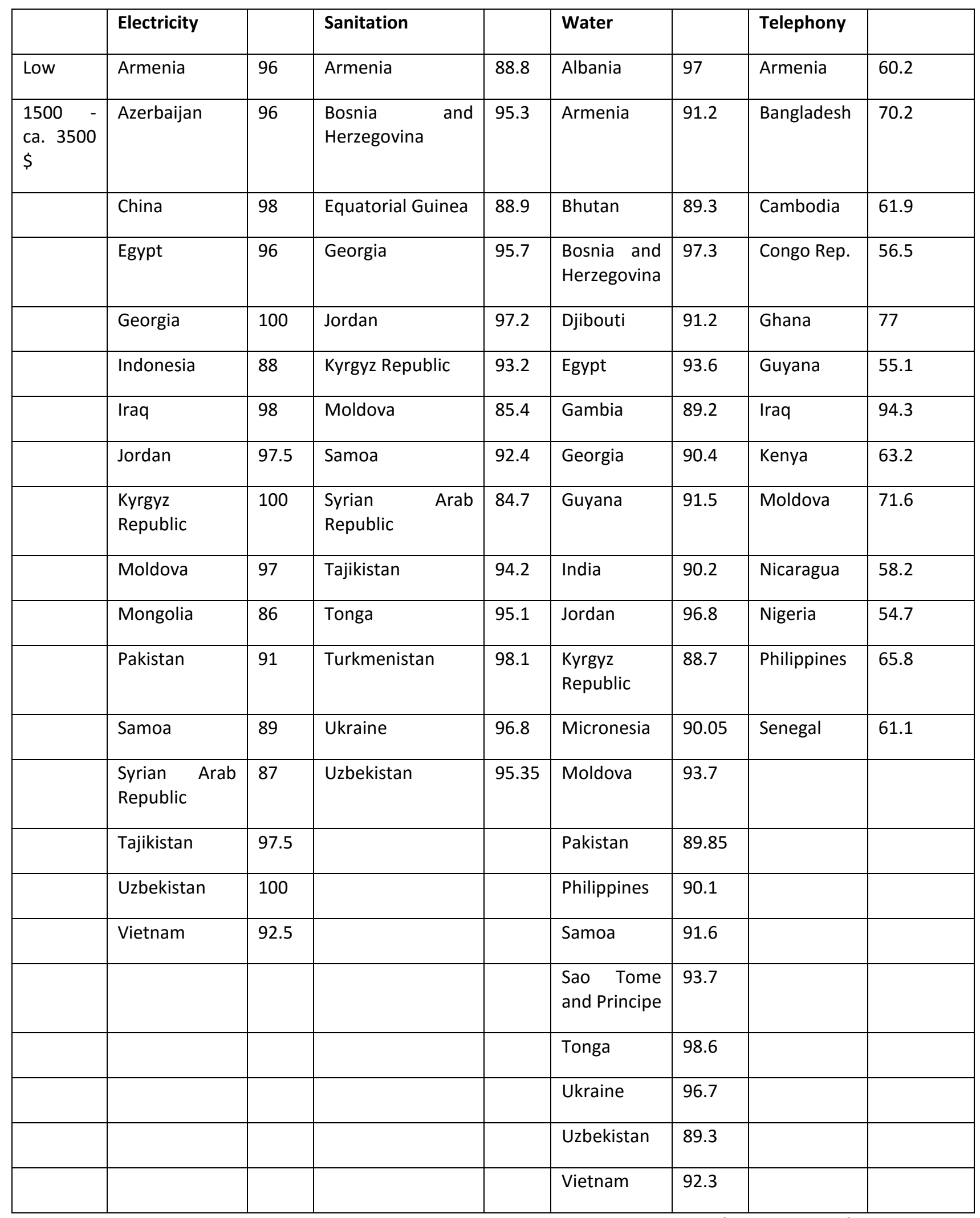

Table S5: Positive relative outliers: countries with high access levels and comparably low incomes (See also Figure 3). Values are median values calculated over all years when a particular country was an "outlier" 


\begin{tabular}{|c|c|c|c|c|c|c|c|c|}
\hline $\begin{array}{l}\text { Medium } \\
\text { Income } \\
3,484- \\
7,556\end{array}$ & Electricity & $<81$ & Sanitation & $<74.7$ & Water & $<65$ & Telephony & $<33.7$ \\
\hline & Angola & 35 & Angola & 55,05 & Angola & 51,4 & Algeria & 31,0 \\
\hline & Bhutan & 72 & Azerbaijan & 73,35 & Azerbaijan & 77,1 & Angola & 29,6 \\
\hline & Bolivia & 80 & Bhutan & 43,4 & Belize & 77,6 & Bolivia & 23,9 \\
\hline & Botswana & 37 & Bolivia & 41,65 & Bolivia & 81,1 & $\begin{array}{l}\text { Dominican } \\
\text { Republic }\end{array}$ & 30,0 \\
\hline & Brazil & 44 & Botswana & 42,75 & Congo, Rep. & 72,2 & El Salvador & 29,9 \\
\hline & Congo, Rep. & 37 & Brazil & 68,4 & $\begin{array}{l}\text { Dominican } \\
\text { Republic }\end{array}$ & 83,4 & Georgia & 33,2 \\
\hline & $\begin{array}{l}\text { Dominican } \\
\text { Republic }\end{array}$ & 78 & Cape Verde & 62,45 & Ecuador & 80 & Guatemala & 15,1 \\
\hline & Fiji & 54,5 & China & 59,95 & El Salvador & 79 & Maldives & 32,3 \\
\hline & Guatemala & 79 & Colombia & 70,85 & $\begin{array}{l}\text { Equatorial } \\
\text { Guinea }\end{array}$ & 50,9 & Namibia & 24,8 \\
\hline & Mauritius & 73,2 & Congo, Rep. & 18 & Guatemala & 83,2 & Paraguay & 29,8 \\
\hline & Namibia & 37 & $\begin{array}{l}\text { Dominican } \\
\text { Republic }\end{array}$ & 73,6 & Indonesia & 82,85 & Peru & 21,9 \\
\hline & Peru & 70,5 & Ecuador & 71,9 & Iraq & 80,1 & Thailand & 25,4 \\
\hline & South Africa & 66 & El Salvador & 61,45 & Mongolia & 83,3 & Tunisia & 28,0 \\
\hline
\end{tabular}




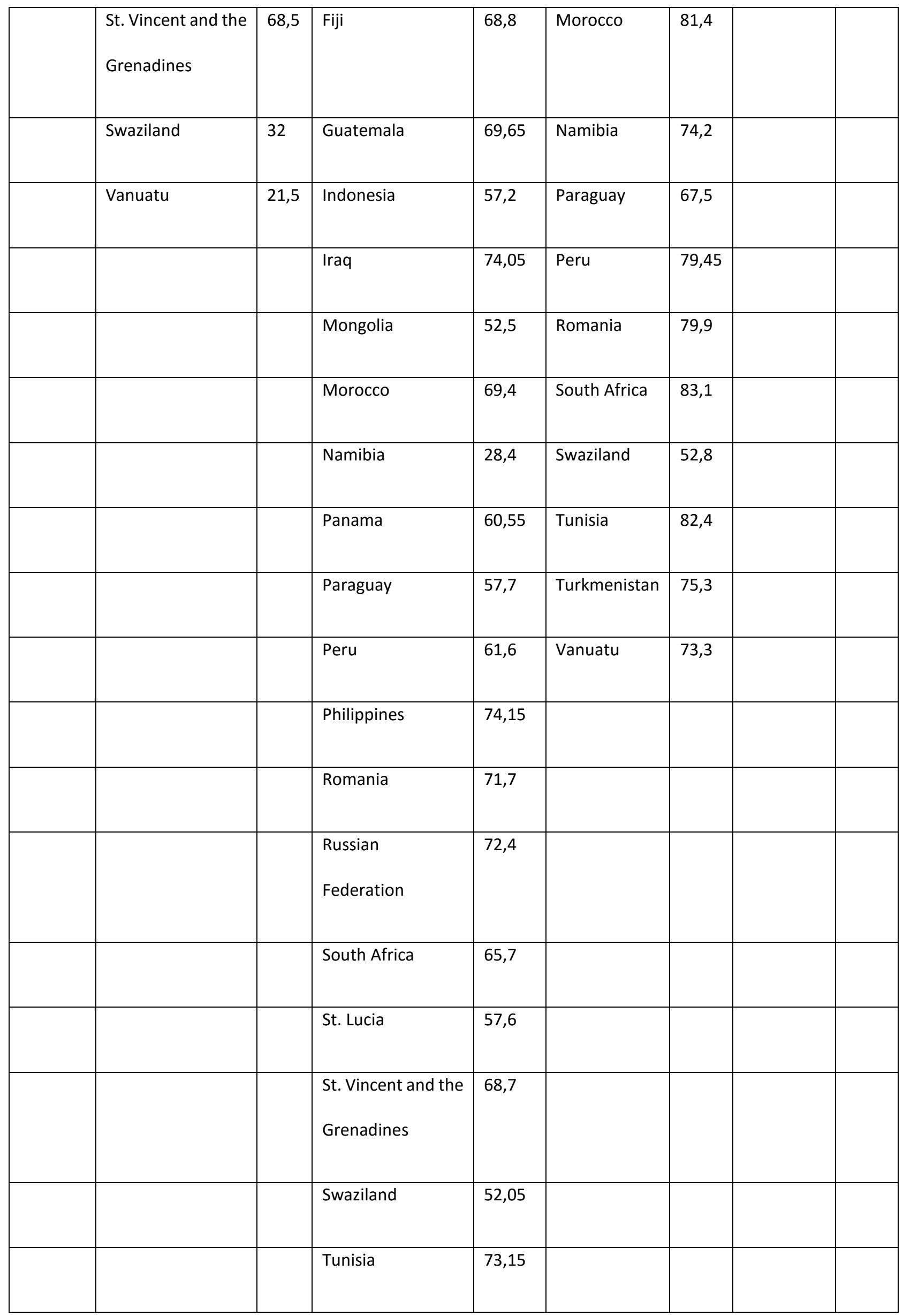




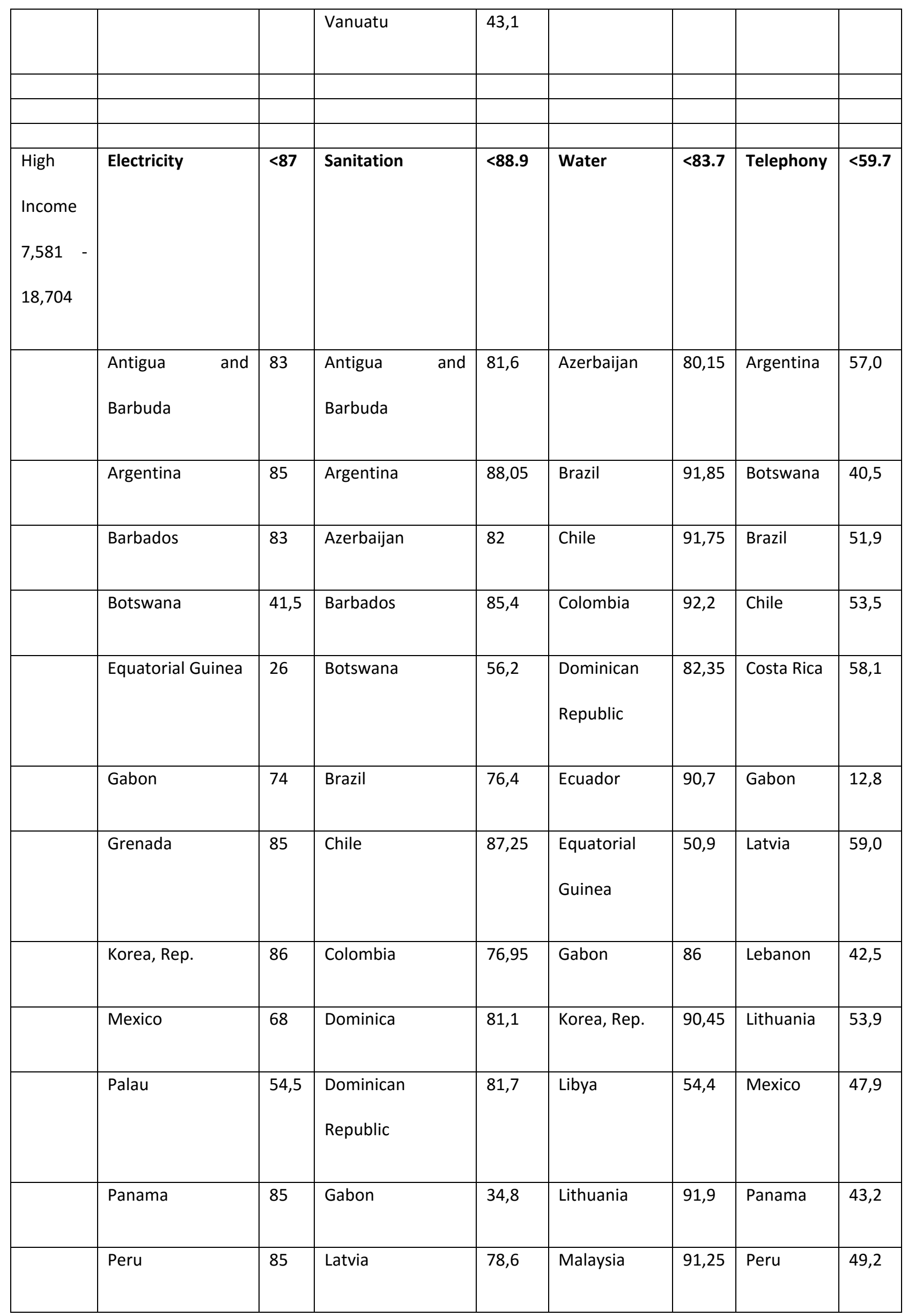




\begin{tabular}{|c|c|c|c|c|c|c|c|}
\hline Seychelles & 24 & Lithuania & 86,7 & Mexico & 87,7 & Romania & 58,0 \\
\hline South Africa & 74 & Malaysia & 87,3 & Oman & 79,55 & $\begin{array}{l}\text { South } \\
\text { Africa }\end{array}$ & 37,6 \\
\hline St. Kitts and Nevis & 83 & Mexico & 75,85 & Palau & 91,55 & Thailand & 22,6 \\
\hline St. Lucia & 85 & Oman & 83,85 & Panama & 90,8 & Tunisia & 58,3 \\
\hline $\begin{array}{l}\text { St. Vincent and the } \\
\text { Grenadines }\end{array}$ & 73 & Palau & 69,35 & Peru & 84,6 & $\begin{array}{l}\text { Venezuela, } \\
\text { RB }\end{array}$ & 34,7 \\
\hline & & Panama & 68,2 & Romania & 87,7 & & \\
\hline & & Peru & 70,4 & South Africa & 88,35 & & \\
\hline & & Romania & 72,1 & $\begin{array}{l}\text { Trinidad and } \\
\text { Tobago }\end{array}$ & 90,4 & & \\
\hline & & $\begin{array}{l}\text { Russian } \\
\text { Federation }\end{array}$ & 71,9 & Turkey & 88,5 & & \\
\hline & & South Africa & 70,55 & Turkmenistan & 71 & & \\
\hline & & St. Kitts and Nevis & 87,3 & $\begin{array}{l}\text { Venezuela, } \\
\text { RB }\end{array}$ & 91,3 & & \\
\hline & & St. Lucia & 62,9 & & & & \\
\hline & & $\begin{array}{l}\text { St. Vincent and the } \\
\text { Grenadines }\end{array}$ & 76,1 & & & & \\
\hline & & Tunisia & 87,8 & & & & \\
\hline & & Turkey & 86,1 & & & & \\
\hline & & Venezuela, RB & 85,5 & & & & \\
\hline
\end{tabular}




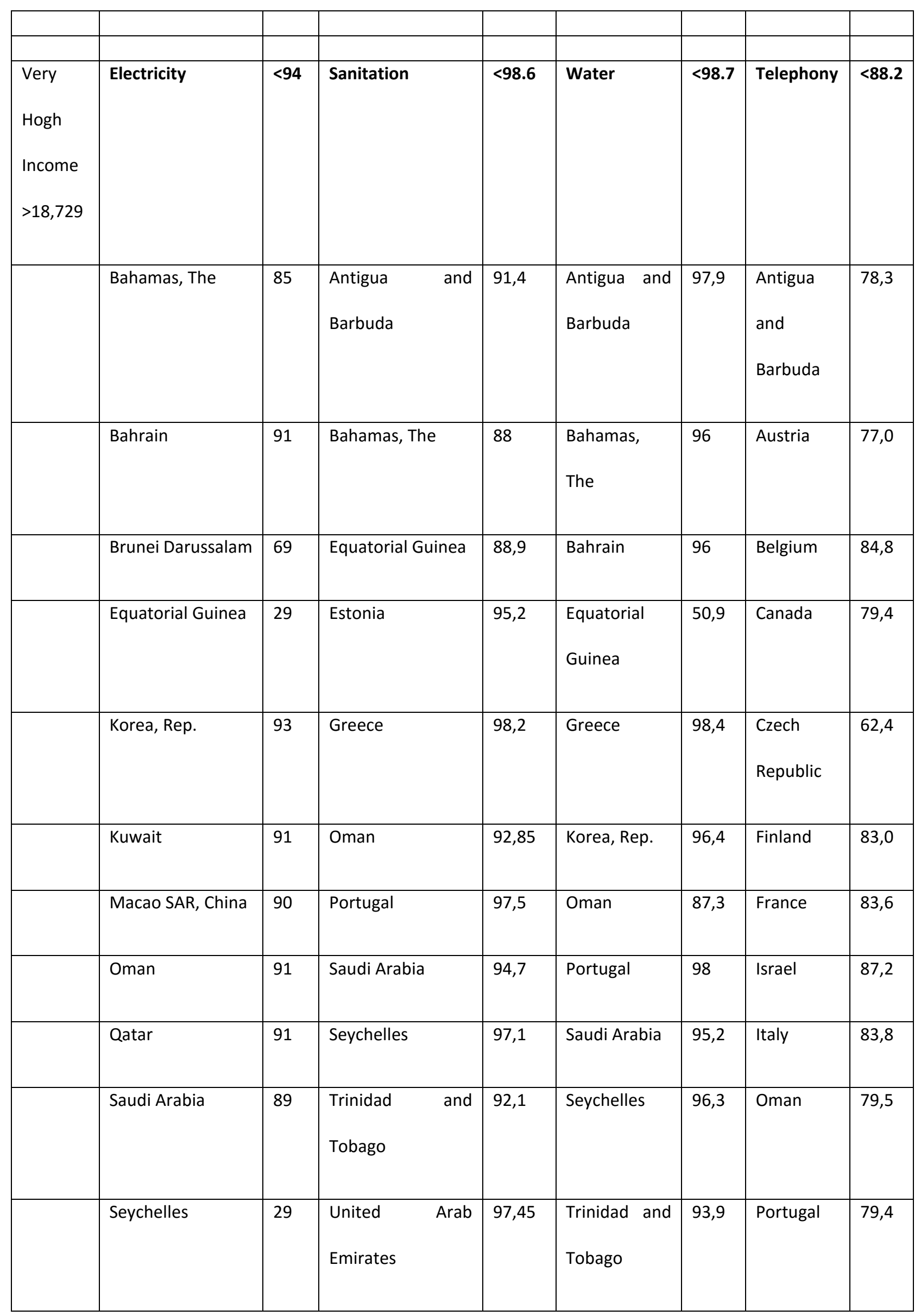




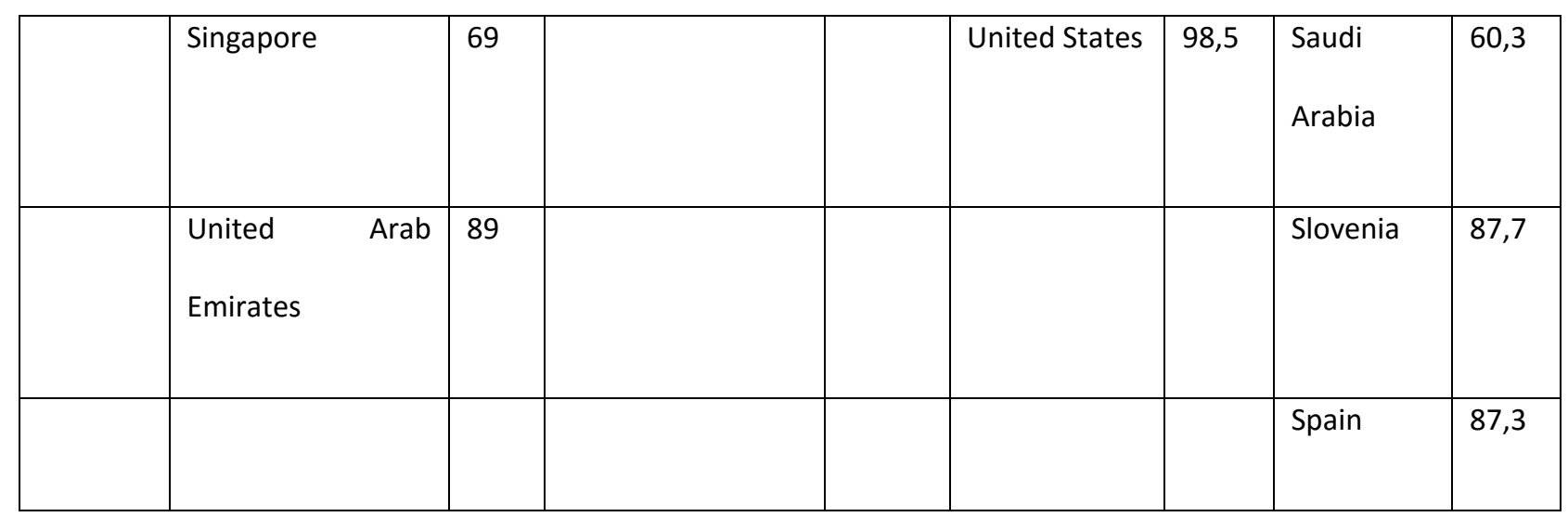

Table S6: Negative relative outliers: countries with low access levels and comparably high incomes (See also Figure 3).

Values are median values calculated over all years when a particular country was an "outlier" 


\section{II) Prediction of access variables}

With Gini and FDI data

Without Gini Data

Telephony
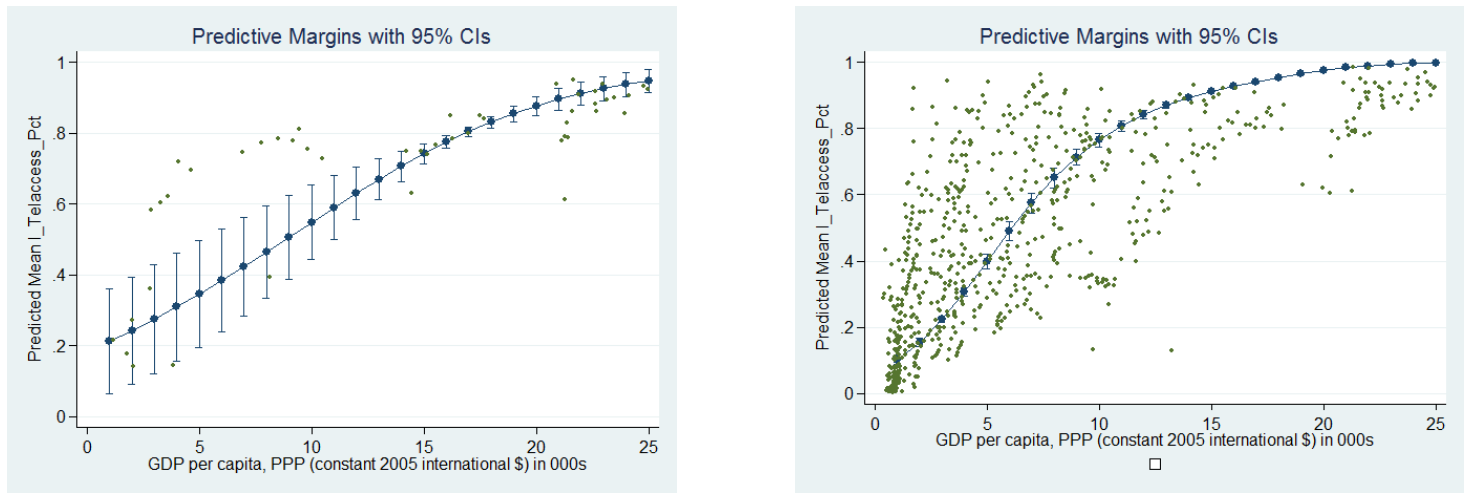

\section{Water}
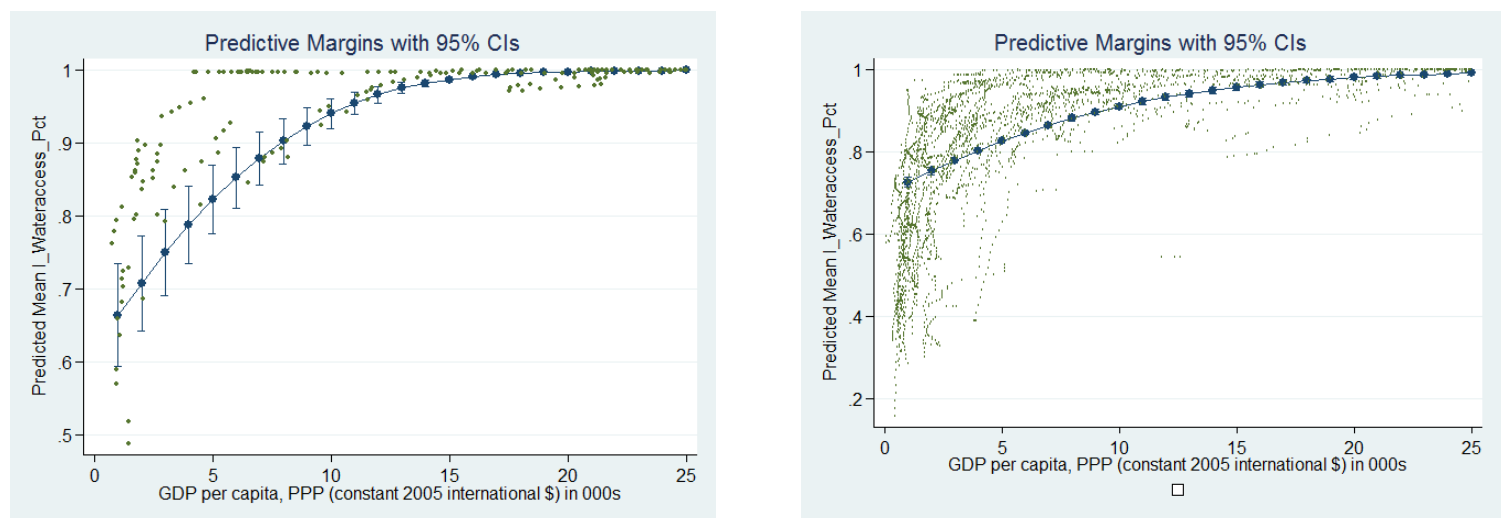

\section{Sanitation}
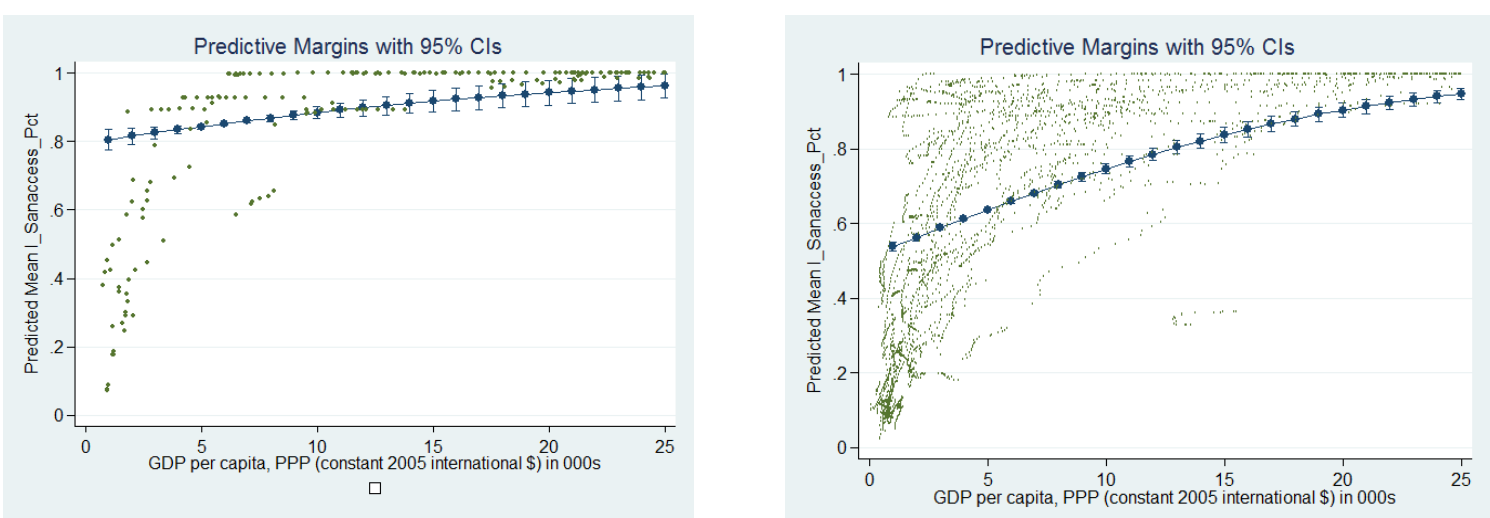


\section{Electricity}
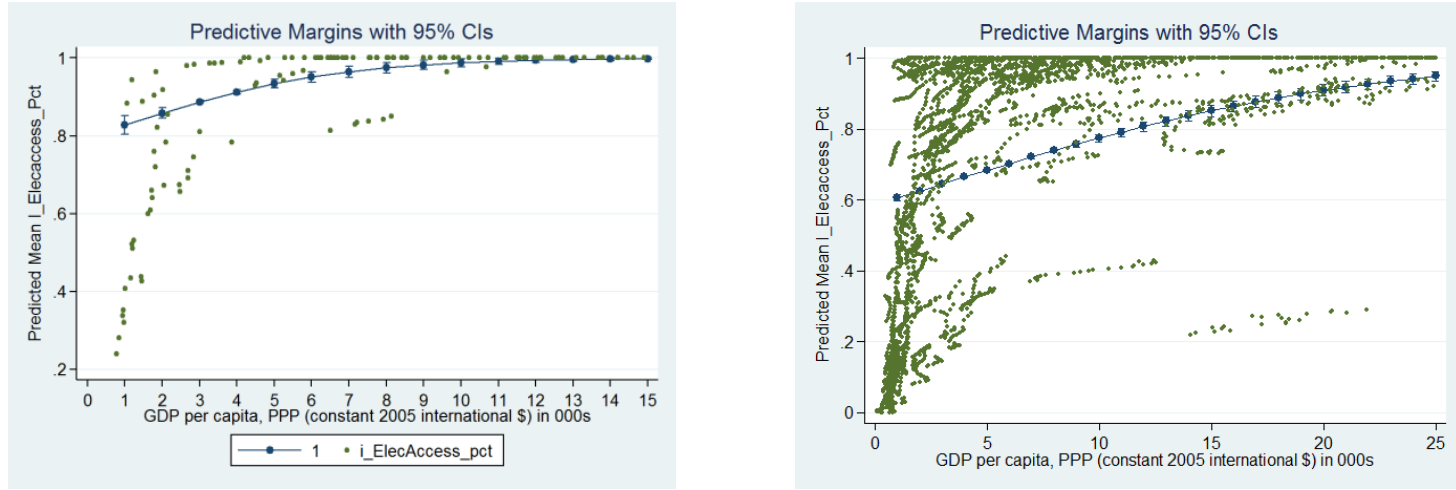

Figure S5: Goodness of fit for four access variables including Gini and FDI data (left column) and excluding it (right column). 


\section{Between Country Effects - Results}

Between Country-Full Model

\begin{tabular}{ccccc}
\hline National Average Access (\%) & Sanitation & Water & Electricity & Telephony \\
\hline GDP per cap (\$PPP ‘00) & 1.38 & 1.27 & 1.57 & 1.14 \\
& $(5.63)^{* * *}$ & $(5.68)^{* * *}$ & $(3.62)^{* * *}$ & $(7.17)^{* * * *}$ \\
Pop density & 1.48 & 1.03 & 0.76 & 1.17 \\
& $(1.30)$ & $(0.11)$ & $(0.79)$ & $(0.58)$ \\
Income inequality (Gini) & 0.97 & 0.96 & 0.93 & 0.99 \\
FDI_avg & $(1.30)$ & $(2.11)^{* *}$ & $(3.33)^{* * *}$ & $(0.64)$ \\
& 1.15 & 1.07 & 1.34 & 1.00 \\
No Obs & $(1.41)$ & $(0.89)$ & $(2.09)^{* *}$ & $(0.04)$ \\
BIC & 28 & 28 & 29 & 26 \\
& -74.21 & -75.98 & -79.08 & -66.57
\end{tabular}

Table S7: Between Country-Full Model. * $p<0.1 ; * *<<0.05 ; * * * p<0.01$. Coefficients in exponentiated form, showing proportionate chage in DV from a unit change in IV. 
Between Country-Parsimonious Model

\begin{tabular}{ccccc}
\hline National \% Access & Sanitation & Water & Electricity & Telephony \\
\hline GDP per cap (\$PPP ‘00) & 1.32 & 1.25 & 1.35 & $(9.18$ \\
& $(8.01)^{* * *}$ & $(6.57)^{* * *}$ & $(4.41)^{* * * *}$ \\
Pop density & 1.01 & 1.01 & 0.99 & $(0.39)$ \\
& $(4.44)^{* * *}$ & $(3.40)^{* * *}$ & $(0.95)$ & 1.00 \\
No Obs & 145 & 145 & 146 & -548.97
\end{tabular}

Table S8: Between Country-Parsimonious Model. * $p<0.1 ; * * p<0.05 ; * * * p<0.01$. Coefficients in exponentiated form, showing proportionate chage in DV from a unit change in IV 
Between Country-Full Model

\begin{tabular}{|c|c|c|c|c|c|c|}
\hline Urban/Rural Access (\%) & San-AccessR & San-AccessU & Water-AccessR & Water-AccessU & Elec-AccessR & Elec-AccessU \\
\hline \multirow[t]{2}{*}{ GDP per cap (\$PPP ‘000) } & 1.25 & 1.40 & 1.20 & 1.32 & 1.45 & 1.38 \\
\hline & $(4.76) * * *$ & $(4.36)^{* * *}$ & $(5.49)^{* * *}$ & $(4.48)^{* * *}$ & $(3.89) * * *$ & $(2.82)^{* * *}$ \\
\hline \multirow[t]{2}{*}{ Pop density } & 1.51 & 1.27 & 1.12 & 1.09 & 0.84 & 0.63 \\
\hline & $(1.31)$ & $(0.64)$ & $(0.44)$ & $(0.38)$ & $(0.45)$ & $(1.06)$ \\
\hline \multirow[t]{2}{*}{ Income inequality (Gini) } & 0.96 & 0.97 & 0.95 & 0.95 & 0.92 & 0.93 \\
\hline & $(1.89)^{*}$ & $(1.42)$ & $(2.96) * * *$ & $(2.72)^{* * *}$ & $(3.36) * * *$ & $(2.78) * * *$ \\
\hline \multirow[t]{2}{*}{ FDI_avg } & 1.17 & 1.13 & 1.01 & 1.18 & 1.26 & 1.21 \\
\hline & $(1.81)^{*}$ & $(1.12)$ & $(0.09)$ & $(2.22)^{* *}$ & $(1.50)$ & $(1.47)$ \\
\hline No Obs & 29 & 28 & 28 & 29 & 29 & 29 \\
\hline $\mathrm{BIC}$ & -76.71 & -74.42 & -75.35 & -80.50 & -77.74 & -79.97 \\
\hline
\end{tabular}

Table S9: Between Country-Full Model. * $p<0.1 ; * *<<0.05 ; * * *<<0.01$. Coefficients in exponentiated form, showing proportionate chage in DV from a unit change in IV. 
Between Country-Parsimonious Model

\begin{tabular}{|c|c|c|c|c|c|c|}
\hline Urban/Rural Access (\%) & Water-AccessR & Water-AccessU & San-AccessR & San-AccessU & Elec-AccessR & Elec-AccessU \\
\hline \multirow[t]{2}{*}{ GDP per cap (\$PPP ‘000) } & 1.18 & 1.18 & 1.27 & 1.29 & 1.31 & 1.30 \\
\hline & $(6.81)^{* * *}$ & $(3.67)^{* * *}$ & $(8.72)^{* * *}$ & $(6.47)^{* * *}$ & $(5.28)^{* * * *}$ & $(3.09) * * *$ \\
\hline \multirow[t]{2}{*}{ Pop density } & 1.00 & 1.00 & 1.00 & 1.01 & 0.94 & 0.99 \\
\hline & $(0.71)$ & $(0.75)$ & $(0.22)$ & $(3.01)^{* * *}$ & $(3.10) * * *$ & $(1.96)^{* *}$ \\
\hline No Obs & 145 & 146 & 146 & 145 & 146 & 146 \\
\hline BIC & -684.80 & -700.98 & -673.36 & -681.16 & -645.55 & -671.43 \\
\hline
\end{tabular}

Table S10: Between Country-Parsimonious Model. * $p<0.1 ; * * p<0.05 ; * * * p<0.01$. Coefficients in exponentiated form, showing proportionate chage in DV from a unit change in IV. 


\section{Within Country Effects - Results}

Within Country-Full Model

\begin{tabular}{|c|c|c|c|c|}
\hline National Average Access (\%) & Elec-Access & Water-Access & Tel-Access & San-Access \\
\hline \multirow[t]{2}{*}{ GDP per cap (\$PPP ‘000) } & 1.47 & 1.45 & 1.26 & 1.11 \\
\hline & $(6.31)^{* * *}$ & $(9.73)^{* * *}$ & $(3.94)^{* * *}$ & $(3.75)^{* * *}$ \\
\hline \multirow[t]{3}{*}{ Pop density ('000 people/sq km } & 3.08 & 1.52 & 0.84 & 3.47 \\
\hline & & & & \\
\hline & $(4.11)^{* * *}$ & $(3.03)^{* * *}$ & $(0.26)$ & $(5.50)^{* * *}$ \\
\hline \multirow[t]{2}{*}{ Income inequality (Gini) } & 1.03 & 1.01 & 0.99 & 1.01 \\
\hline & $(2.93) * * *$ & $(1.06)$ & $(0.58)$ & $(1.32)$ \\
\hline \multirow[t]{2}{*}{ FDI } & 1.00 & 0.98 & 0.98 & 1.00 \\
\hline & $(0.36)$ & $(1.96)^{*}$ & $(1.40)$ & $(0.12)$ \\
\hline No Obs & 193 & 177 & 48 & 182 \\
\hline $\mathrm{BIC}$ & -836.55 & -739.92 & -123.52 & -775.06 \\
\hline
\end{tabular}

Table S11: Within Country-Full Model. $* p<0.1 ; * *<<0.05 ; * * *<<0.01$. Coefficients in exponentiated form, showing Relative Proportions Ratio from a unit change. 
Within Country-Parsimonious Model

\begin{tabular}{ccccc}
\hline National Average Access (\%) & Elec-Access & Water-Access & Tel-Access & San-Access \\
\hline GDP per cap (\$PPP ‘000) & 1.17 & 1.19 & 1.78 & 1.16 \\
& $(19.34)^{* * *}$ & $(17.02)^{* * *}$ & $(11.71)^{* * *}$ & $(17.81)^{* * * *}$ \\
Pop density ('000 people/sq km & 1.01 & 1.02 & 1.28 & 1.01 \\
arable) & & & & $(3.48)^{* * *}$ \\
& $(4.56)^{* * *}$ & $(2.18)^{* *}$ & $(3.19)^{* * *}$ & 2,789 \\
No Obs & 2,923 & 2,825 & 722 & $-20,878.44$ \\
BIC & $-22,060.35$ & $-21,186.79$ & $-4,102.29$ &
\end{tabular}

Table S12: Within Country-Parsimonious Model. * $p<0.1 ; * * p<0.05 ; * * * p<0.01$. Coefficients in exponentiated form, showing Relative Proportions Ratio from a unit change. 
Within Country-Full Model

\begin{tabular}{|c|c|c|c|c|c|c|}
\hline Urban/Rural Access (\%) & Water-AccessR & Water-AccessU & San-AccessR & San-AccessU & Elec-AccessR & Elec-AccessU \\
\hline \multirow[t]{2}{*}{ GDP per cap (\$PPP ‘000) } & 1.44 & 1.36 & 1.11 & 1.04 & 1.36 & 1.24 \\
\hline & $(10.40)^{* * *}$ & $(7.92)^{* * * *}$ & $(4.22)^{* * *}$ & $(2.57)^{* *}$ & $(4.98)^{* * *}$ & $(1.83)^{*}$ \\
\hline \multirow[t]{3}{*}{ Pop density ('000 people/sq } & 1.75 & 0.72 & 5.27 & 1.47 & 3.94 & 3.43 \\
\hline & & & & & & \\
\hline & $(3.19)^{* * *}$ & $(3.19)^{* * *}$ & $(5.61)^{* * *}$ & $(2.85)^{* * *}$ & $(3.66)^{* * *}$ & $(5.89)^{* * *}$ \\
\hline \multirow[t]{2}{*}{ Income inequality (Gini) } & 1.01 & 1.01 & 1.01 & 1.01 & 1.02 & 1.02 \\
\hline & $(0.99)$ & $(1.32)$ & $(1.08)$ & $(1.43)$ & $(2.39)^{* *}$ & $(1.34)$ \\
\hline \multirow[t]{2}{*}{ FDI } & 0.98 & 0.96 & 1.00 & 0.99 & 0.99 & 1.00 \\
\hline & $(2.15)^{* *}$ & $(3.09)^{* * *}$ & $(0.38)$ & $(0.96)$ & $(0.75)$ & $(0.26)$ \\
\hline No Obs & 177 & 193 & 184 & 188 & 193 & 193 \\
\hline $\mathrm{BIC}$ & -739.75 & -836.66 & -776.43 & -811.49 & -831.20 & -836.61 \\
\hline
\end{tabular}


Within Country-Parsimonious Model

\begin{tabular}{|c|c|c|c|c|c|c|}
\hline $\begin{array}{l}\text { Urban/Rural Access } \\
(\%)\end{array}$ & Water-AccessR & Water-AccessU & San-AccessR & San-AccessU & Elec-AccessR & Elec-AccessU \\
\hline \multirow{3}{*}{$\begin{array}{l}\text { GDP per cap (\$PPP } \\
\text { '000) }\end{array}$} & 1.18 & 1.11 & 1.18 & 1.09 & 1.20 & 1.14 \\
\hline & & & & & & \\
\hline & $(19.73)^{* * *}$ & $(11.28)^{* * *}$ & $(18.56)^{* * *}$ & $(13.70)^{* * *}$ & $(17.90)^{* * *}$ & $(11.81)^{* * *}$ \\
\hline \multirow[t]{2}{*}{ Pop density } & 1.02 & 1.03 & 1.00 & 1.01 & 1.01 & 1.01 \\
\hline & $(2.76)^{* * *}$ & $(1.88)^{*}$ & $(0.37)$ & $(2.45)^{* *}$ & $(3.15)^{* * *}$ & $(5.03) * * *$ \\
\hline No Obs & 2,825 & 2,888 & 2,805 & 2,833 & 2,923 & 2,923 \\
\hline BIC & $-21,187.09$ & $-21,749.84$ & $-21,002.63$ & $-21,277.92$ & $-22,046.00$ & $-22,059.00$ \\
\hline
\end{tabular}


Urban/Rural Access (\%)

Within Country-Full Model - With One Year Lag

\begin{tabular}{|c|c|c|c|c|c|c|}
\hline & Water-AccessR & Water-AccessU & San-AccessR & San-AccessU & Elec-AccessR & Elec-AccessU \\
\hline GDP per cap (\$PPP ‘000) & $\begin{array}{l}1.45 \\
(9.66) * * *\end{array}$ & $\begin{array}{l}1.36 \\
(7.30)^{* * * *}\end{array}$ & $\begin{array}{l}1.10 \\
(3.70) * * *\end{array}$ & $\begin{array}{l}1.05 \\
(2.71)^{* * *}\end{array}$ & $\begin{array}{l}1.28 \\
(3.50)^{* * *}\end{array}$ & $\begin{array}{c}1.14 \\
(1.17)\end{array}$ \\
\hline $\begin{array}{l}\text { Pop density ('000 } \\
\text { people/sq km arable) }\end{array}$ & $\begin{array}{l}1.90 \\
(3.42)^{* * *}\end{array}$ & $\begin{array}{l}0.80 \\
(1.93)^{*}\end{array}$ & $\begin{array}{c}5.73 \\
(5.56)^{* * *}\end{array}$ & $\begin{array}{c}1.52 \\
(3.00)^{* * *}\end{array}$ & $\begin{array}{l}5.00 \\
(4.21)^{* * *}\end{array}$ & $\begin{array}{l}3.80 \\
(6.39) * * *\end{array}$ \\
\hline Income inequality (Gini) & $\begin{array}{l}1.00 \\
(0.48)\end{array}$ & $\begin{array}{l}1.01 \\
(0.94)\end{array}$ & $\begin{array}{c}1.01 \\
(0.96)\end{array}$ & $\begin{array}{c}1.01 \\
(1.24)\end{array}$ & $\begin{array}{l}1.02 \\
(1.90)^{*}\end{array}$ & $\begin{array}{l}1.02 \\
(1.13)\end{array}$ \\
\hline FDI & $\begin{array}{l}0.98 \\
(2.29) * *\end{array}$ & $\begin{array}{l}0.96 \\
(2.97) * * *\end{array}$ & $\begin{array}{c}1.00 \\
(0.45)\end{array}$ & $\begin{array}{c}0.99 \\
(0.89)\end{array}$ & $\begin{array}{c}0.99 \\
(1.27)\end{array}$ & $\begin{array}{c}0.98 \\
(1.25)\end{array}$ \\
\hline No Obs & 187 & 203 & 195 & 197 & 203 & 203 \\
\hline $\mathrm{BIC}$ & -904.45 & -956.24 & -943.22 & -956.09 & $-1,051.64$ & -940.26 \\
\hline
\end{tabular}

Table S15: Within Country-Full Model with 1-Yr Lag * $p<0.1 ; * * p<0.05 ; * * *<<0.01$. Coefficients in exponentiated form, showing Relative Proportions Ratio from a unit change. 
Within Country-Full Model - With Three Year Lag

\begin{tabular}{|c|c|c|c|c|c|c|}
\hline & Water-AccessR & Water-AccessU & San-AccessR & San-AccessU & Elec-AccessR & Elec-AccessU \\
\hline GDP per cap (\$PPP ‘000) & $\begin{array}{l}1.51 \\
(9.11)^{* * *}\end{array}$ & $\begin{array}{l}1.38 \\
(6.09) * * *\end{array}$ & $\begin{array}{l}1.09 \\
(3.22)^{* * *}\end{array}$ & $\begin{array}{l}1.05 \\
(3.04)^{* * *}\end{array}$ & $\begin{array}{l}1.31 \\
(4.37)^{* * *}\end{array}$ & $\begin{array}{l}1.22 \\
(1.68)^{*}\end{array}$ \\
\hline $\begin{array}{l}\text { Pop density ('000 } \\
\text { people/sq km arable) }\end{array}$ & $\begin{array}{l}1.99 \\
(3.99)^{* * *}\end{array}$ & $\begin{array}{l}0.82 \\
(2.02)^{* *}\end{array}$ & $\begin{array}{l}4.90 \\
(5.94)^{* * *}\end{array}$ & $\begin{array}{l}1.36 \\
(2.33)^{* *}\end{array}$ & $\begin{array}{l}5.49 \\
(5.99)^{* * *}\end{array}$ & $\begin{array}{l}3.25 \\
(6.14)^{* * *}\end{array}$ \\
\hline Income inequality (Gini) & $\begin{array}{l}1.00 \\
(0.20)\end{array}$ & $\begin{array}{l}1.01 \\
(0.48)\end{array}$ & $\begin{array}{l}1.01 \\
(0.74)\end{array}$ & $\begin{array}{l}1.01 \\
(1.25)\end{array}$ & $\begin{array}{l}1.02 \\
(1.56)\end{array}$ & $\begin{array}{l}1.01 \\
(0.76)\end{array}$ \\
\hline FDI & $\begin{array}{l}0.98 \\
(2.15)^{* *}\end{array}$ & $\begin{array}{l}0.96 \\
(2.85) * * *\end{array}$ & $\begin{array}{l}1.01 \\
(0.74)\end{array}$ & $\begin{array}{l}0.99 \\
(0.91)\end{array}$ & $\begin{array}{l}0.99 \\
(0.96)\end{array}$ & $\begin{array}{l}0.98 \\
(1.73)^{*}\end{array}$ \\
\hline No Obs & 204 & 220 & 213 & 214 & 220 & 220 \\
\hline $\mathrm{BIC}$ & $-1,004.41$ & $-1,073.14$ & $-1,087.50$ & $-1,056.89$ & $-1,153.69$ & $-1,062.33$ \\
\hline
\end{tabular}

Table S16: Within Country-Full Model with 3-Yr Lag * $p<0.1 ; * * p<0.05 ; * * * p<0.01$. Coefficients in exponentiated form, showing Relative Proportions Ratio from a unit change. 
Within Country-Full Model - With One Year Lag

\begin{tabular}{|c|c|c|c|c|}
\hline & Elec-Access & Water-Access & Tel-Access & San-Access \\
\hline GDP per cap (\$PPP ‘000) & $\begin{array}{l}1.37 \\
(4.31)^{* * *}\end{array}$ & $\begin{array}{l}1.48 \\
(9.36)^{* * *}\end{array}$ & $\begin{array}{l}1.12 \\
(2.56)^{* *}\end{array}$ & $\begin{array}{l}1.10 \\
(3.53)^{* * *}\end{array}$ \\
\hline Pop density ('000 people/sq km arable) & $\begin{array}{l}3.74 \\
(4.52)^{* * *}\end{array}$ & $\begin{array}{l}1.62 \\
(3.17)^{* * *}\end{array}$ & $\begin{array}{l}222.05 \\
(2.28)^{* *}\end{array}$ & $\begin{array}{l}3.69 \\
(5.46) * * *\end{array}$ \\
\hline Income inequality (Gini) & $\begin{array}{l}1.02 \\
(2.24)^{* *}\end{array}$ & $\begin{array}{l}1.00 \\
(0.48)\end{array}$ & $\begin{array}{c}1.00 \\
(0.09)\end{array}$ & $\begin{array}{l}1.01 \\
(1.25)\end{array}$ \\
\hline FDI & $\begin{array}{c}0.99 \\
(1.14)\end{array}$ & $\begin{array}{l}0.98 \\
(1.90)^{*}\end{array}$ & $\begin{array}{c}0.98 \\
(0.91)\end{array}$ & $\begin{array}{l}1.00 \\
(0.35)\end{array}$ \\
\hline $\begin{array}{l}\text { No Obs } \\
\text { BIC }\end{array}$ & $\begin{array}{l}203 \\
-1.057 .07\end{array}$ & $\begin{array}{r}187 \\
-888.96\end{array}$ & $\begin{array}{r}54 \\
-147.18\end{array}$ & $\begin{array}{r}192 \\
-951.23\end{array}$ \\
\hline
\end{tabular}

Table S17: Within Country-Full Model with 1-Yr Lag * $p<0.1 ; * *<<0.05 ; * * * p<0.01$. Coefficients in exponentiated form, showing Relative Proportions Ratio from a unit change. 
Within Country-Full Model - With Three Year Lag

\begin{tabular}{|c|c|c|c|c|}
\hline & Elec-Access & Water-Access & Tel-Access & San-Access \\
\hline 13_gdppercappppconstK & $\begin{array}{l}1.43 \\
(4.83)^{* * *}\end{array}$ & $\begin{array}{l}1.53 \\
(8.76)^{* * *}\end{array}$ & $\begin{array}{c}1.04 \\
(0.88)\end{array}$ & $\begin{array}{l}1.09 \\
(3.40)^{* * *}\end{array}$ \\
\hline 13_popdensarableK & $\begin{array}{l}3.78 \\
(6.30)^{* * *}\end{array}$ & $\begin{array}{l}1.64 \\
(3.89)^{* * *}\end{array}$ & $\begin{array}{l}185.05 \\
(5.27)^{* * *}\end{array}$ & $\begin{array}{l}3.24 \\
(5.86)^{* * *}\end{array}$ \\
\hline 13_rmultiGini & $\begin{array}{l}1.02 \\
(1.69)^{*}\end{array}$ & $\begin{array}{c}1.00 \\
(0.26)\end{array}$ & $\begin{array}{c}0.99 \\
(0.45)\end{array}$ & $\begin{array}{c}1.01 \\
(0.98)\end{array}$ \\
\hline 13_fdi & $\begin{array}{c}0.99 \\
(0.82)\end{array}$ & $\begin{array}{c}0.98 \\
(1.74)^{*}\end{array}$ & $\begin{array}{c}0.97 \\
(1.66)^{*}\end{array}$ & $\begin{array}{c}1.00 \\
(0.53)\end{array}$ \\
\hline No Obs & 220 & 204 & 68 & 211 \\
\hline BIC & $-1,148.48$ & $-1,010.00$ & -202.09 & $-1,048.49$ \\
\hline
\end{tabular}

Table S18: Within Country-Full Model with 3-Yr Lag * $p<0.1 ; * * p<0.05 ; * * * p<0.01$. Coefficients in exponentiated form, showing Relative Proportions Ratio from a unit change. 